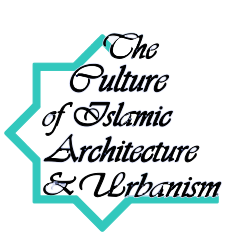

\title{
A Reappraisal of the Principles and Indicators of the "Sustainable Community" to Apply It to the Urbanism of Islamic World in the Age of Globalization
}

\author{
Maryam Roosta ${ }^{*}$ \\ Assistant Professor, Faculty of Art and Architecture, Shiraz University, Shiraz, Iran \\ (Received 3 Apr 2020, Accepted 9 Jun 2020)
}

In the historical study of the Muslim urban tradition, a primary features is the physical manifestation of Islam's "social dimensions" and, in particular, the key concept of "the Ummah." In the process of transformations induced by "globalization," the social layer of cities and the physical implications of it appear to be among the layers affected by several factors. In the last two decades, the social aspect of the sustainable development, termed as "social sustainability" and deemed by experts as the most important dimension and the ultimate goal of sustainability, is a concept that through a more precise understanding of its indices one can achieve the characteristics of a "sustainable society" to apply it to urban planning and designing. This article seeks to redefine indicators of the concept of "sustainable society" by studying the social dimensions of the tradition of urbanization of Muslims in a comparative approach, while analyzing the "social' effects of globalization on the city, and defining a "local" and "strategic" framework. The main research questions were: What are the most important social challenges of globalization in cities? How can the social principles of Islam and its emergence in the tradition of Muslim urbanization, on the one hand, and sustainable local community indicators, on the other, be used to meet the social challenges of globalization in cities? In addition to these two main questions, another sub-question was raised: To what extent are the social principles of Islam and the principles of a sustainable local community analogous in the conceptual framework of sustainable development? The study adopts an "interpretative" approach and uses the "quality" strategy and the "content analysis" method and "rational reasoning" to analyze the data deriving from documentary studies. After reviewing the social dimensions of globalization in cities, while adapting the spatial indices of the "sustainable community" and the socio-spatial aspects of the urbanization tradition of Muslims, a conceptual and strategic framework in line with the social challenges of globalization for use in urban design guidance documents was presented. To answer the second question, scholarly views on the principles and indicators of a sustainable community, on the one hand, and the social principles of Islam and its manifestation on the historical tradition of Muslim urbanization, on the other, were studied. Meanwhile, in order to answer the research sub-question, the two conceptual areas were aligned. According to this analysis, Islam's recommendation of "strong social relationships" has the most to do with sustainable community indicators. Also, "Strong neighborhood relationships", "Social supervision" and "Practicing Islamic social rules" as the most important social principles of Islam in exposure with social challenges of globalization was explained. This paper presents a conceptual and strategic framework for addressing the social challenges of globalization in cities using the corresponding social principles of Islam, as well as relevant indicators of sustainable local community, for application in urban design and planning. In future research, quantification of these strategies will be followed up by quantitative methods of field and case studies.

Keywords: Sustainable Community, Globalization, Social principles of Islam, Muslims Urbanism Tradition.

${ }^{*}$ Corresponding author. E-mail: m-roosta@shirazu.ac.ir

Copyright $(2020$, the Authors / This open-access article is published under the terms of the Creative Commons AttributionNonCommercial 4.0 International License which permits Share (copy and redistribute the material in any medium or format) and Adapt (remix, transform, and build upon the material) under the Attribution-NonCommercial .terms 


\title{
بازنگَىى اصول و شاخصهاى (اجتماع يايدار ) بلمنظور

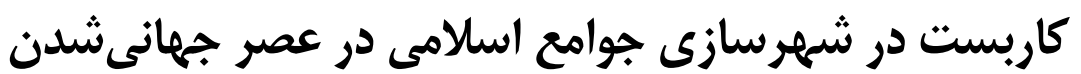

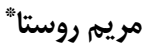 \\ استاديار دانشكده هنر و معمارى، دانشخاه شيراز، شيراز، ايران.

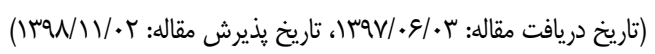

در بررسى تاريخى سنت شهرسازى مسلمانان، يكى از مهمترين بارزها، تجلى كالبدى مفهوم كليدى (امت)، است. به

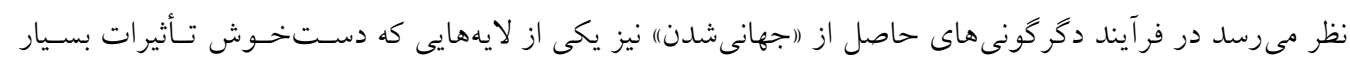

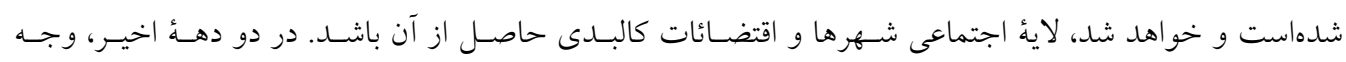

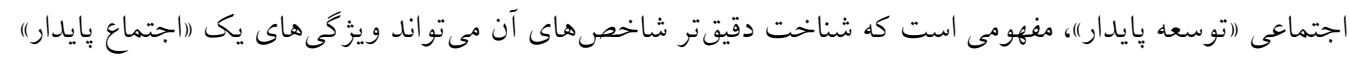

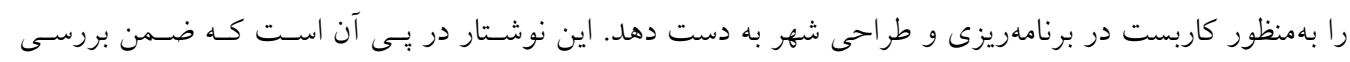

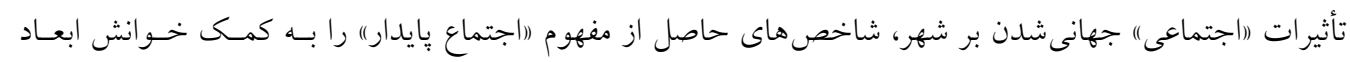

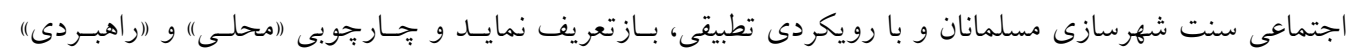

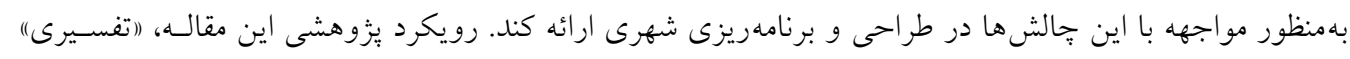

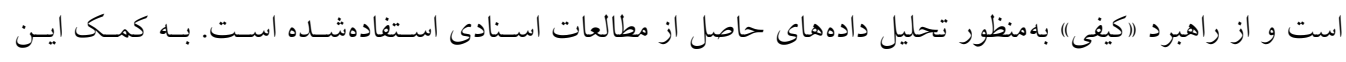

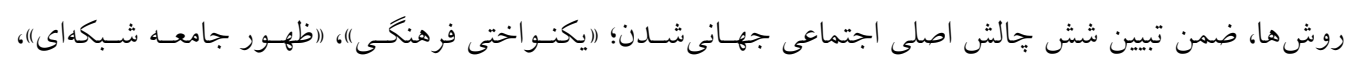

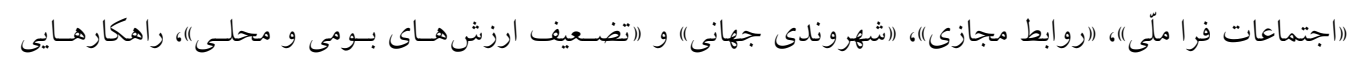

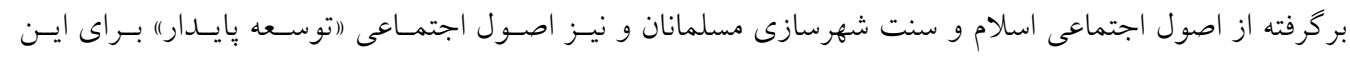

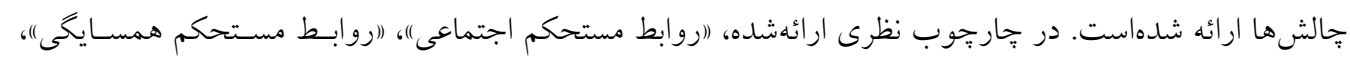

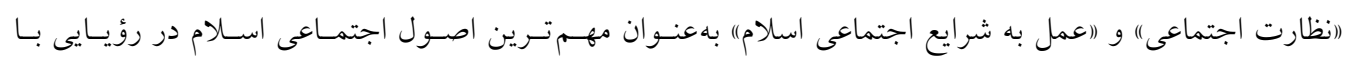

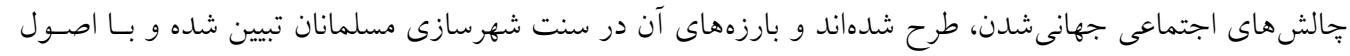

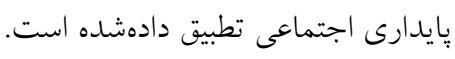

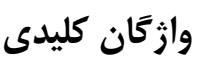
اجتماع بايدار، جهانى شدن، امت، شهرسازى جوامع اسلامى. "نويسندة مسئول مكاتبات: m-roosta@shirazu.ac.ir" 
اسلام، بهعنوان دينى كه بنيان خـود را بــر اجتمـاع قـرار

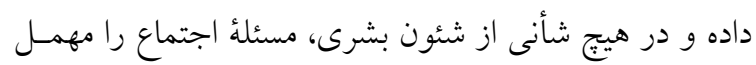

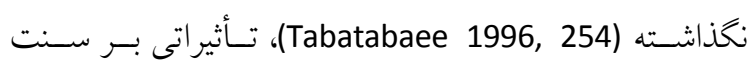

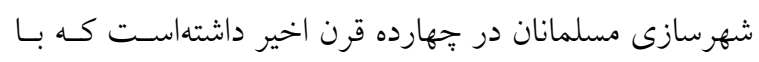
مرور اين سنتها و دلالتهاى آن در ابعاد اجتماعى، مىتوان به راهبردهاى شهرسـازانهاى بـراى كاربسـت در شهرسـازى ائس جوامع اسلامى در عصر حاضر، دست يافت. به نظرمسىرســ بخش قابلتوجهى از اصول اجتماعى اسلام و تأثيرات آن بـر

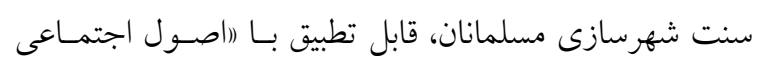

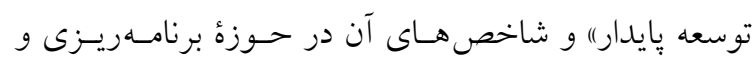
طراحى شهرى باشد. اين نوشتار در بيى آن است كه با مطالعهُ سه حوزه نظرى ((ابعـاد اجتمـاعى جهـانى شــن)،، (اصـول و شاخصهاى اجتماع محلى يايدار) و (اصول اجتماعى اسـلام و تجلى آن در سنت شهرسازى مسلمانان) و به كمك اصـول

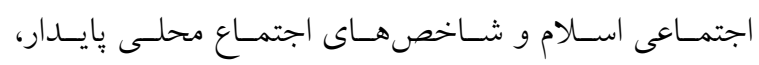

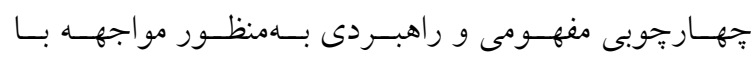
جالشهاى اجتماعى جهانىشدن در شهرها تدوين كند.

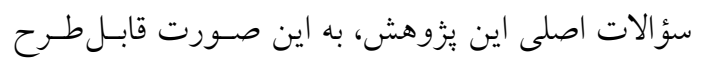
است؛ مهمترين جالشهاى اجتماعى جهانىشــن در شهرها كدام است؟ جِكونه مىتوان از اصول اجتماعى اسلام و بـروز

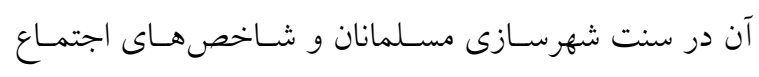
محلى يايدار بهمنظور مواجهه با اين جالشهـا در طراحسى و برنامهريزى شهرى بهـره كرفـت؟ در ضـمن ايسن دو سـؤال

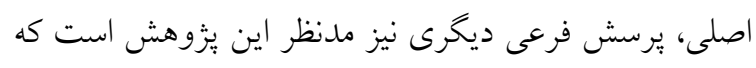

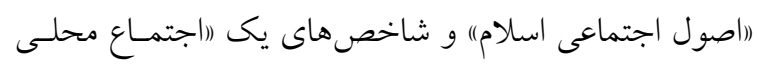

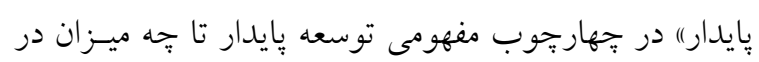
تشابه و اشتراك با هم قرار دارند؟

كتابخانهاى لازم جمع آورى شده و به كمك راهبرد (اكيفى") و روش هاى (اتحليل محتواى كيفى") و نيز (استدلال منطقى)، اين

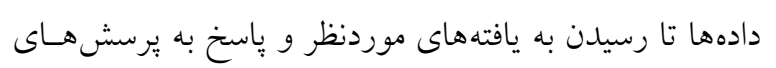

جهانى شدن همراه بـا الزامـات آن يعنسى انقـلاب اطلاعـات، فنّاورى ارتباطات، مجازى سازى، خصوصى سازى و اقتصاد و جامعه شبكهاى، جريانى ظهور يافته در دهههاى اخيـر اسـت

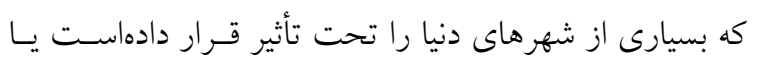

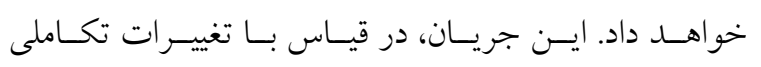

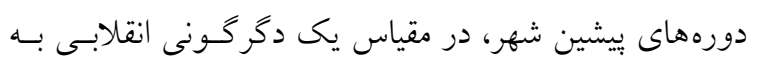
نظر مىرسد و در كل، متفاوت با كذشته است.

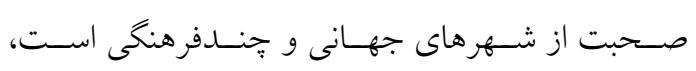
صحبت از بين المللى شدن و جهانوطن كرايى است، صحبت از تكثر هويتها، تفكرات ارتباطى جديد و هويت ريزومسى'

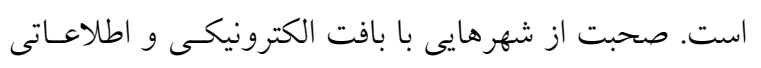

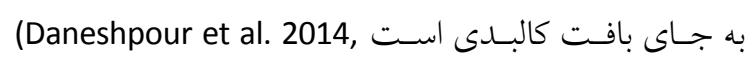
(225. جايى كه به كفته كاستلز، تكنولوزى اطلاعـات، سـبب

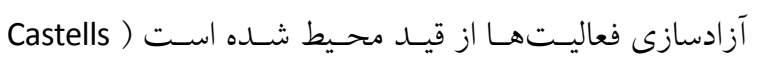
.(2002

اين جريان همزمان با رواج كفتمان توسعهُ يايدار در دنيا

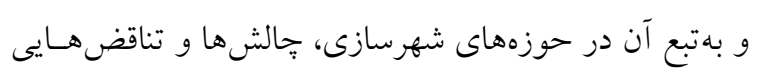
را ايجاد كرده كه لازم است در قالب يزّوهش هاى علمسى بــه

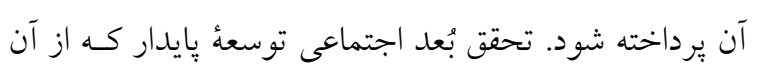

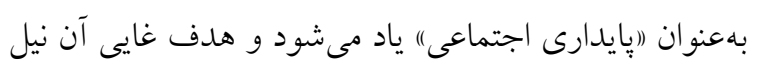

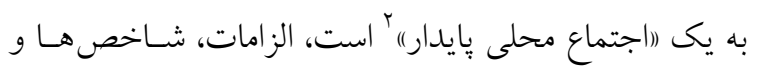

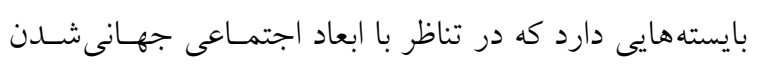

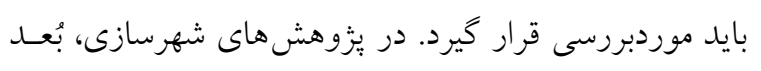
اجتماعى توسعهُ پِايدار و درواقع (پيايدارى اجتماعى)، بهنعنوان قابليت يك محيط شهرى، بهمنظور استمرار حضور يكيارجه، عادلانه و همهشمول گروههاى مختلف اجتمـاعى در شـهر و تعامل سالم آنها در اين محيطها، تعريف و تبيين شده است.

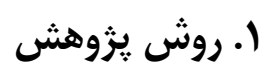
رويكرد اين يزٔوهش در روش شؤنساسى، ("تفسيركرايى)" اسـت و

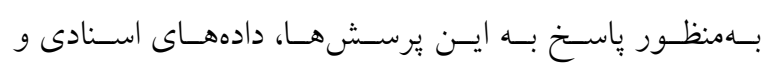


بازنخرى اصول و شاخصهاى "اجتماع پايدار" بهمنظور كاربست در شهر سازى جوامع اسلامى در عصر جهانىشن

هستند در شرايط جهانى شدن، بسيارى از شاخصهـاى بـومى

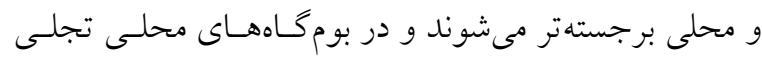

مى يابند (Pishgahifar 2001, 158). يوراحمد و همكاران، افزايش به همبيوستختى و ارتباطـات

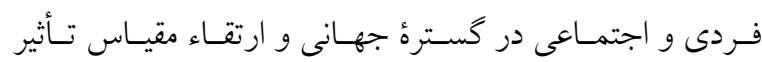

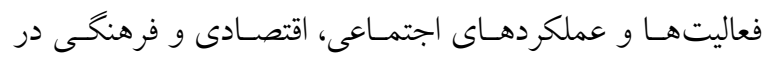

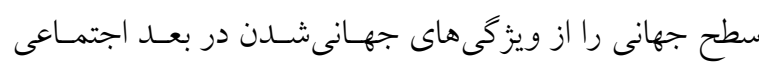
مى دانند (Pourahmad et al. 2011, 32).

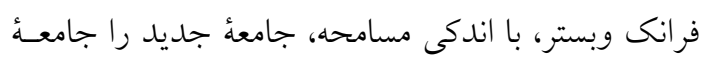

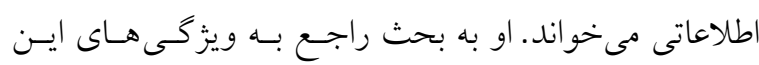

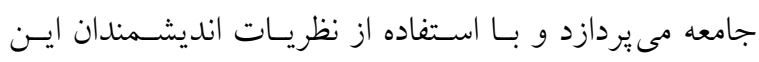

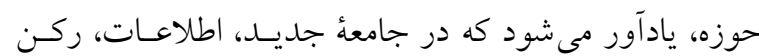
اساسى جامعه است (Webster 2001).

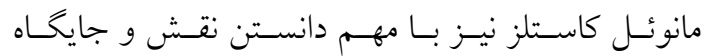

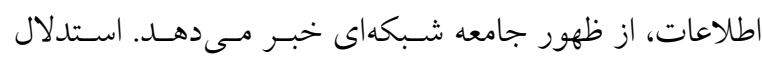

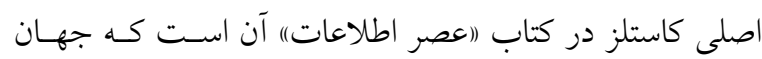
جديد بهصورت يك شبكه درآمده است، شبكهاى كه تارويود

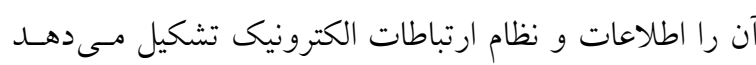

.(Castells 2002)

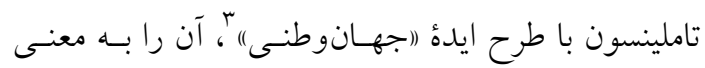

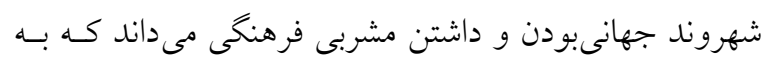

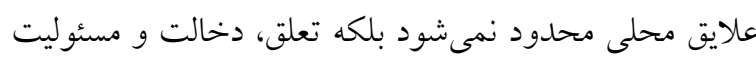

جهانى را به رسميت مىشناسد (Tomlinson 2014, 78).

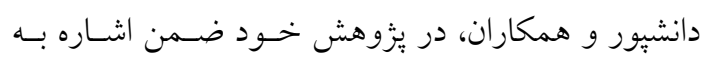

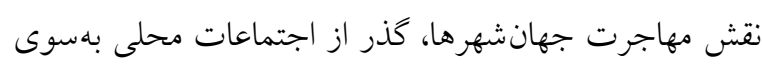

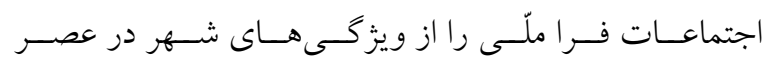

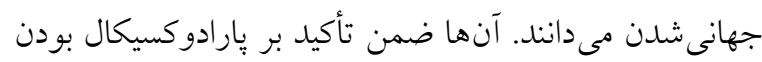

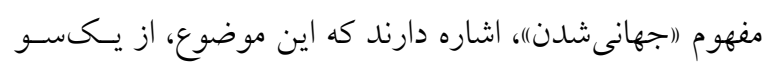

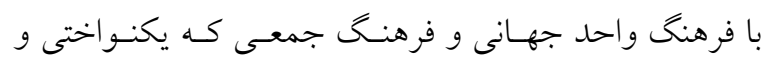

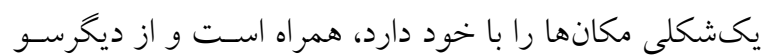

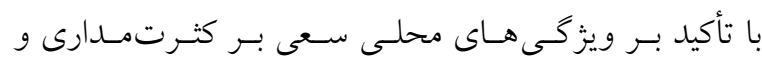

קندشكلى بودن دارد (Daneshpour et al. 2014, 224). در فضاى شهر جهانى امـروز و تحـت تـأثير فضـاهاى

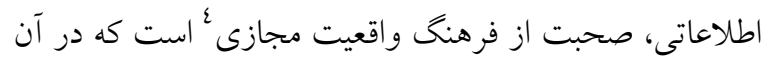

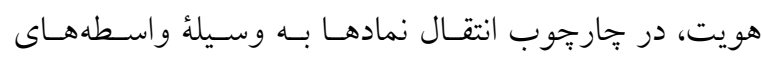

يُوهش، در جنا مر حله تحليل شدهاند. ("تحليل محتواى كيفى)، نوعى روش تحقيـق در خــدمت فرتيل

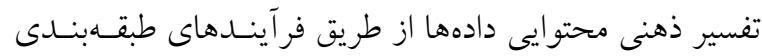

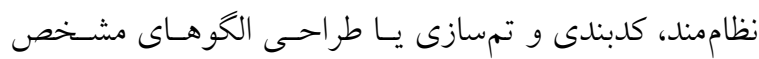

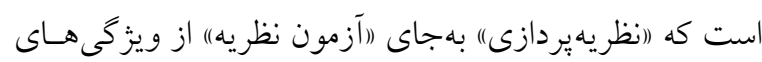

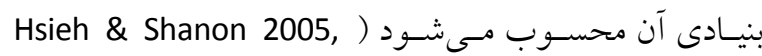

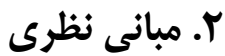

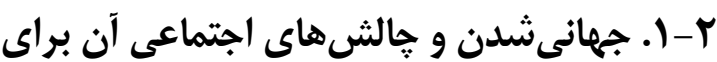

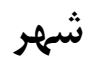

جهانىشدن واقعيت اجتماعى گريزنايذيرى ارزيسابى مسى تشـود

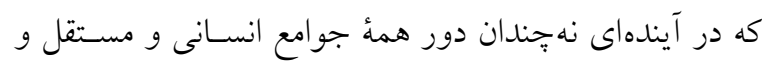

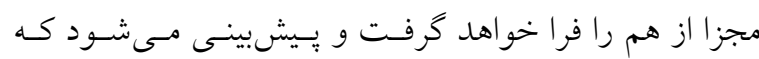

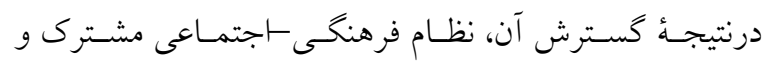

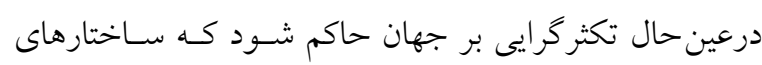

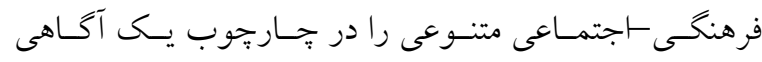

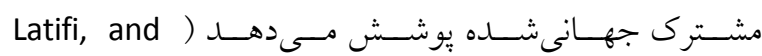

.(Davoodvandi 2009, 189

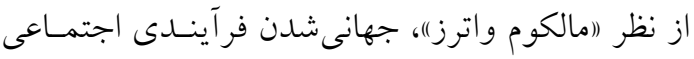

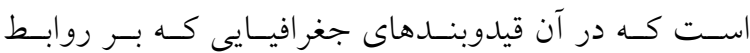
اجتماعى و فرهنكى سايه افكنـاه اسـت، از بـين مسىرود و

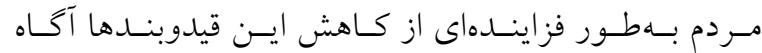
مىشوند (Waters 2000, 12). آنتونى گيدنز، جهانى شدن را

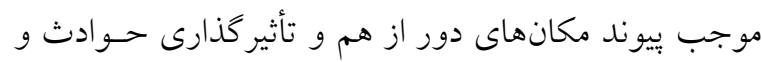

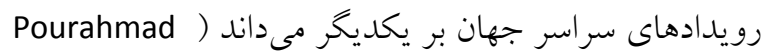
.(et al. 30 در ابعـاد اجتمــاعى و فرهنخــى، دو تلقـى عمـــه، از

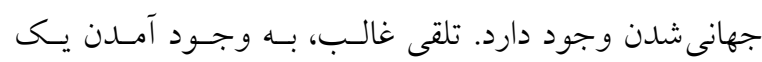

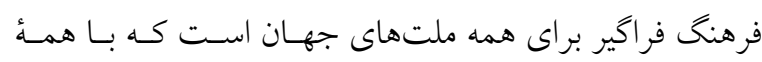

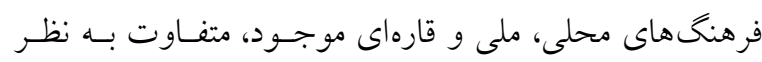

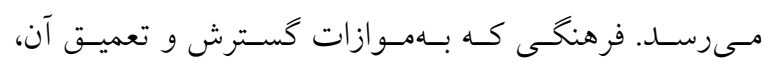

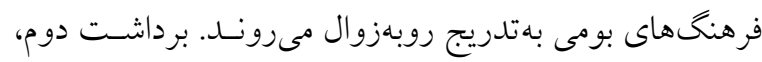

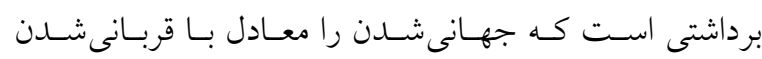

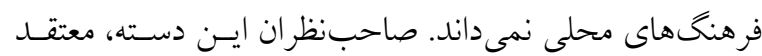




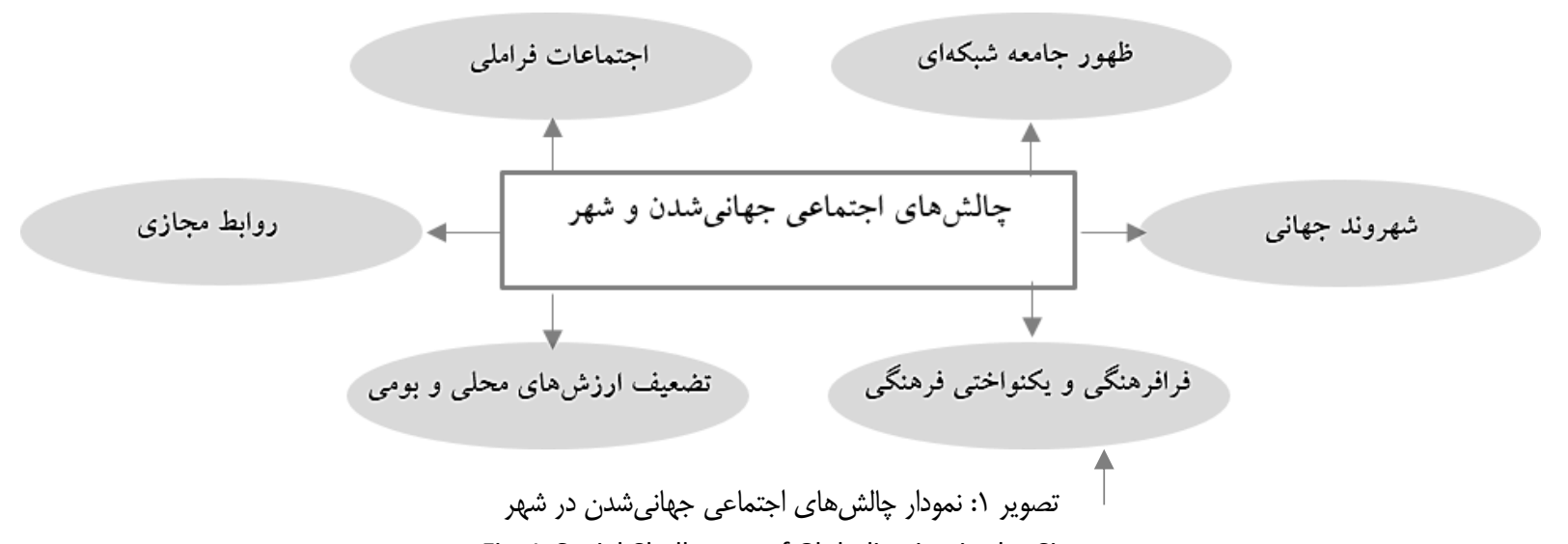

Fig. 1: Social Challenges of Globalization in the City

اجتماعى)، (اعــدالت اجتمـاعى") و (شــموليت اجتمـاعى) را از

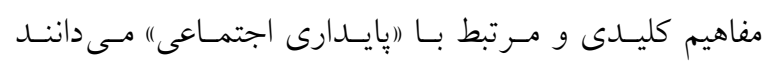
Hemani \& Das 2015, 174; Mazumdar et al. 2017, 125; ) .(Bramley \& Power 2009, 34

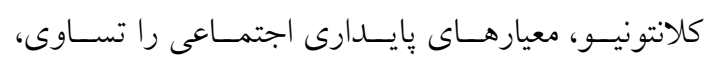

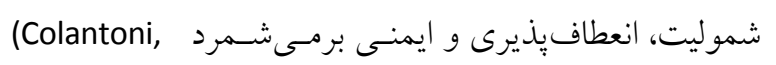

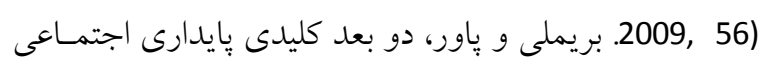
را تساوى اجتماعى و يايدارى اجتماع محلى مسىدانتـد. آنهـا

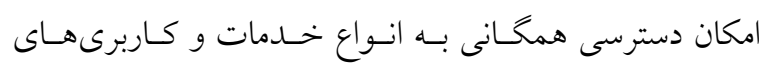

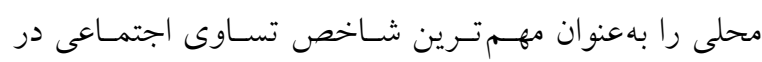

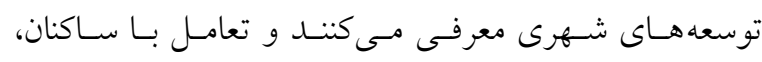

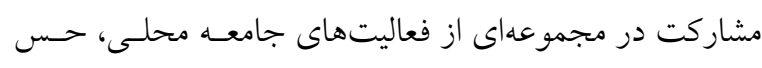

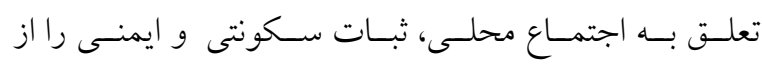

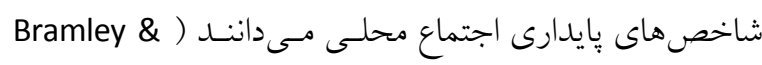

.(Power 2009, 35

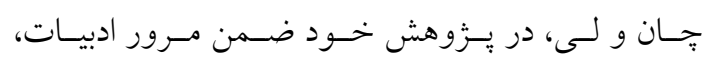

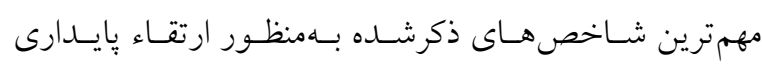

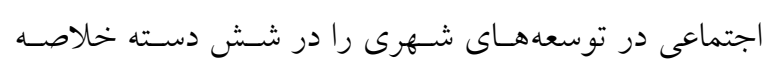

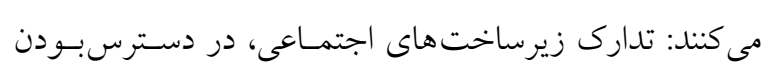

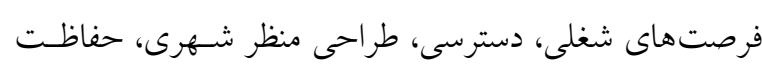

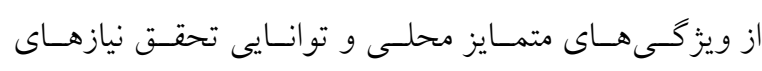

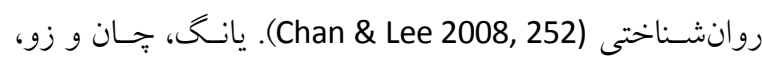

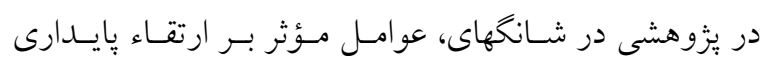

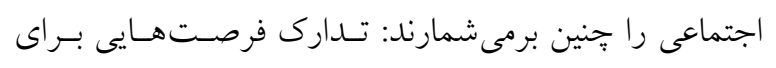

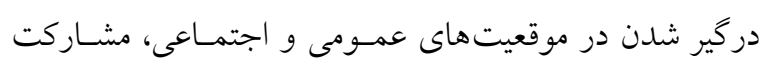

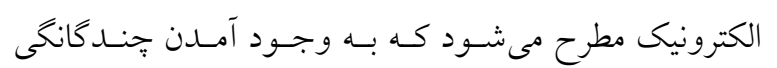

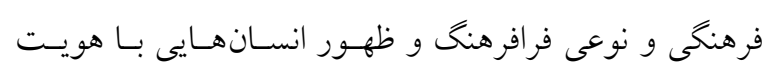

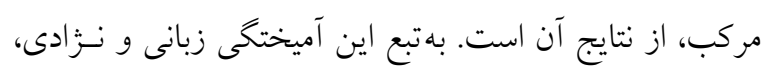

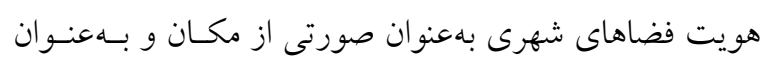

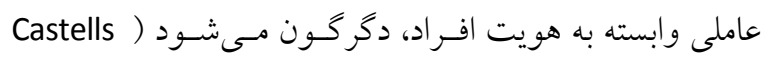

.(2002, 152

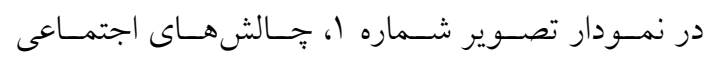

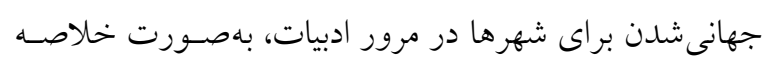

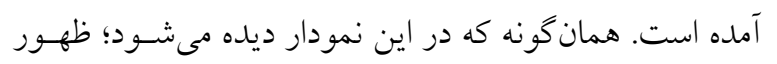

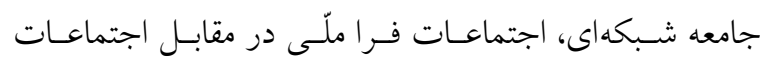

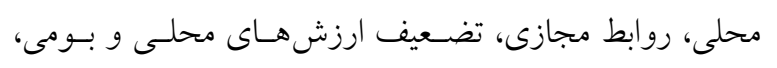

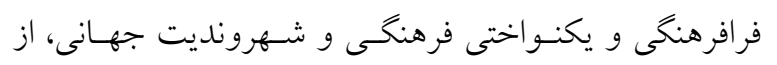

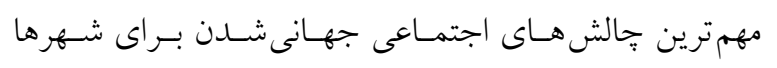

$$
\text { محسوب مىشوند. }
$$

\section{r-r. شهرسازى و اجتماع محلى يايدار}

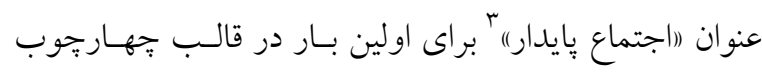

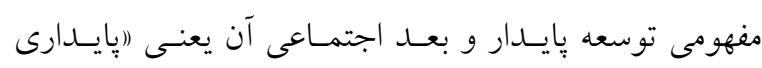

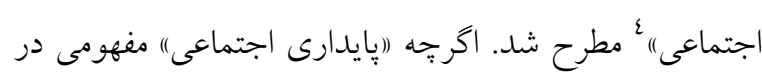

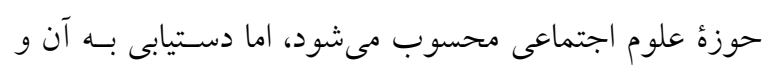

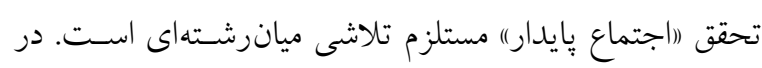

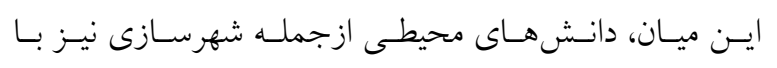

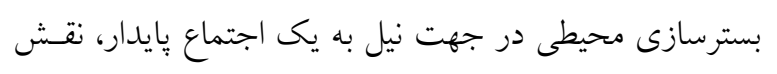
بسزايى ايفا مى كنند. در ثيزوهش ها، جهار مفهوم (اسرمايه اجتماعى)، (انسجام 
بازنكرى اصول و شاخصهاى "اجتماع بايدار" بهمنظور كاربست در شهر سازى جوامع اسلامى در عصر جهانى شدن

مؤسسة ODPM در يزوهشى، يك اجتماع محلـى بايسـار

را داراى هشت ويزگى مى داند: فعال، همهشمول، امن، اداره و

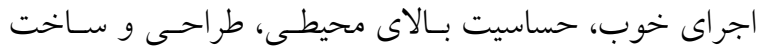

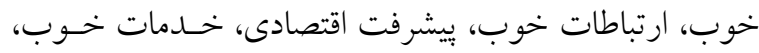
شر ايط عادلانه براى همه (ODPM 2006, 46).

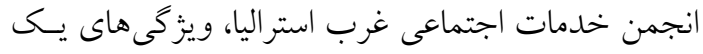

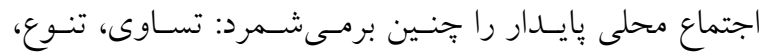

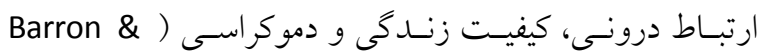

.(Gauntlett 2002, 67

پارتريج، كيفيت زندگى، تساوى، شـموليت، دسترسى و و

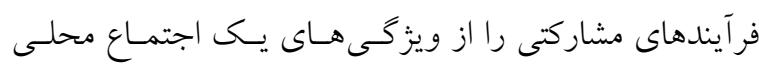

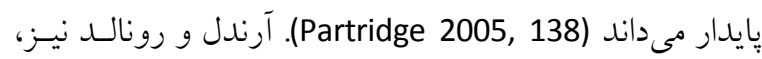

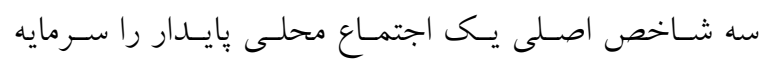

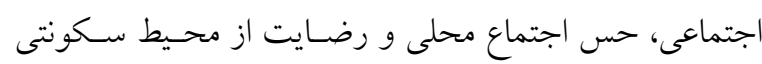

مى مدانند (Arundel \& Ronald 2015, 28).
اجتماعى، حفظ هويت فرهنگ و حافظـهُ جمعى مشـترى،

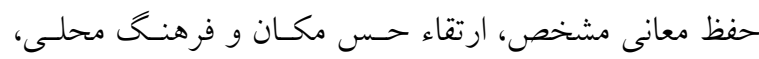

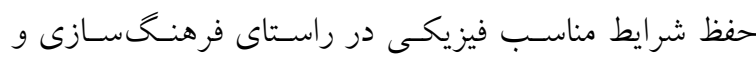
آموزش (Yung, Chan \& XU 2011, 98). در دو منبع حاصل از يزوهشهايى در هند، يُزوهشخران،

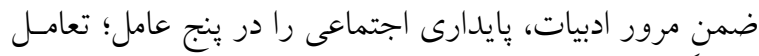

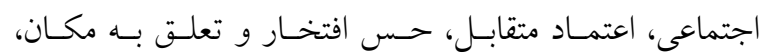

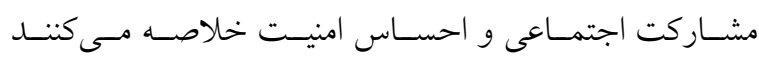
Hemani, Das \& Chowdhury 2016, 172; Hemani \& Das )

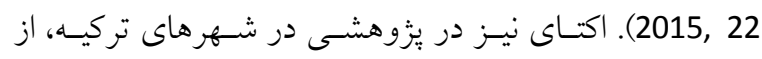

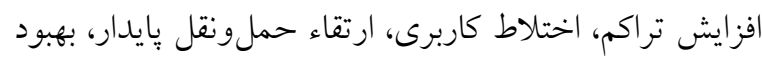

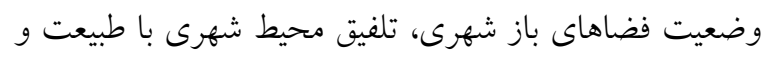

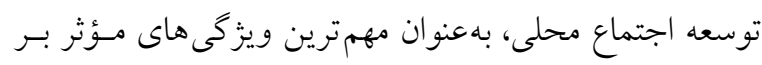

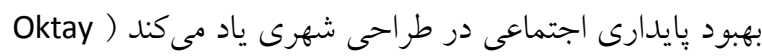

. (2004, 28

جدول (: ابعاد و شاخصهاى اجتماع محلى يايدار در مرور ادبيات

Table 1: Sustainable Community Dimensions and Indicators in Literature Review

\begin{tabular}{|c|c|c|c|}
\hline ابعاد و شاخصهاى اجتماع محلى پايدار & سال يزوهش & نام يثرهش & \\
\hline تساوى - تنوع - ارتباط درونى - كيفيت زندگى - دموكراسى & 2002 & $\begin{array}{l}\text { Barron } \\
\text { and } \\
\text { Gauntlett }\end{array}$ & 1 \\
\hline 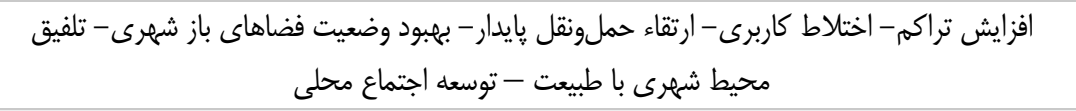 & 2004 & Oktay & r \\
\hline كيفيت زندكى - تساوى - شموليت- دسترسى - فر آيندهاى مشاركتى & 2005 & Partridge & r \\
\hline 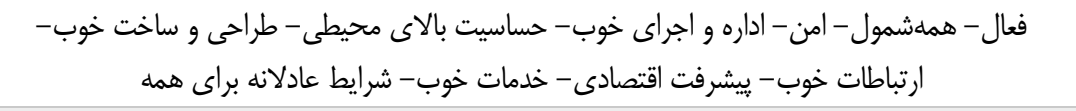 & 2006 & ODPM & f \\
\hline 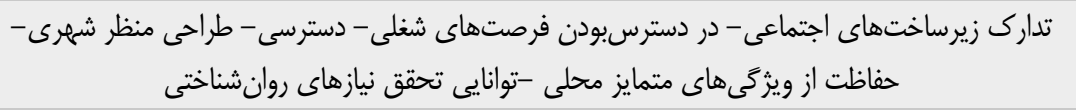 & 2008 & Chan and Lee & $\Delta$ \\
\hline تعامل با ساكنان - مشاركت در جامعه محلى - حس تعلق به اجتماع محلى - ثبات سكونتى - ايمنى & 2009 & $\begin{array}{l}\text { Bramley } \\
\text { and } \\
\text { Power }\end{array}$ & $\varepsilon$ \\
\hline قلمرو عمومى جذاب- مسكن خوب- كيفيت مطلوب - محيط محلى دسترسىيذير - همسايكى بيادهمدار & 2009 & $\begin{array}{l}\text { Dempsy } \\
\text { et al. }\end{array}$ & $\checkmark$ \\
\hline 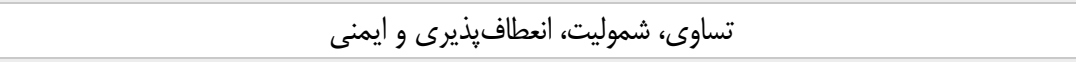 & 2009 & Colantonio & $\wedge$ \\
\hline 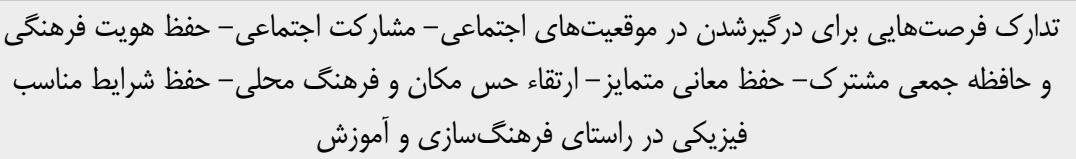 & 2011 & $\begin{array}{l}\text { Yung, } \\
\text { Chan and Xu }\end{array}$ & 9 \\
\hline سر مايه اجتماعى - رضايت از محيط سكونتى - حس اجتماع محلى & 2015 & $\begin{array}{l}\text { Arundel } \\
\text { and } \\
\text { Ronald }\end{array}$ & 1 . \\
\hline تعامل اجتماعى، اعتماد متقابل، حس افتخار و تعلق به مكان، مشاركت اجتماعى و احساس امنيت & 2015 & $\begin{array}{l}\text { Hemani } \\
\text { and } \\
\text { Das }\end{array}$ & 11 \\
\hline
\end{tabular}




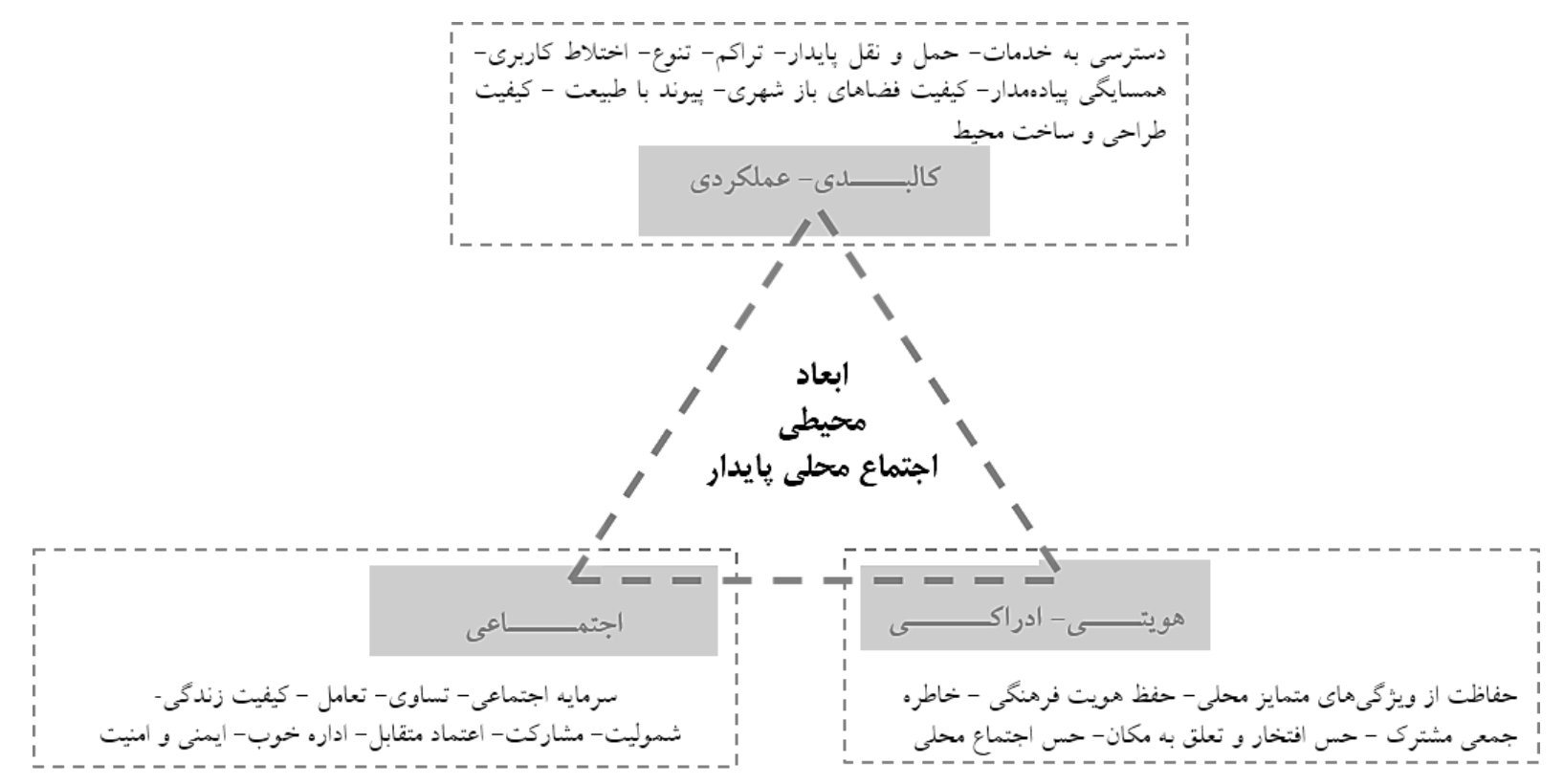

تصوير r: ابعاد محيطى يك اجتماع محلى پايدار

Fig. 2: Environmental Dimensions of a Sustainable Community

ديخر بر روابط خويشـاوندى متكسى نبـود بلكـه از اعتقـادات مشترى دينى برمى خاست (Izutsu 2001, 96). اصول اجتماعى اسلام، بر شكل شهرهاى مسلمانان تـأثير بسيار كذاشته است تا آنجا كه برخـى معتقـــ هسـتند وجــوه

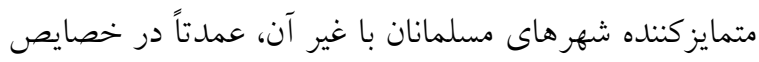
اجتماعى جامعه شهرى ساكن در شـهرهاى اسـلامى و غربسى است (Pourahmad \& Mousavi 2010, 2 ). تحقق مفهوم كليدى (امت) در شهرها و جوامـع اسـلامى مستلزم توجه و يايبندى به اصول و دسـتوراتى اسـت كـه در هفت دسته زير به آن اشاره شده و تجليات آن در شهرسـازى بـ به

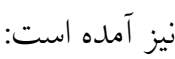
الف) روابط مستحكم و تعاملات اجتماعى: اسـلام بـــ روابط اجتماعى بهمنظور كاهش انزواى مردم از ديخـــان و بــه

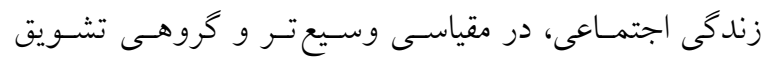
مى كند. (مصابره)) و (امرابطه)) دو مغهوم و دستور قرآنى هستند كه به هدف استحكام روابط اجتماعى در جامعسه اسـلامى بـه آسـ آنها توصيهشده است.

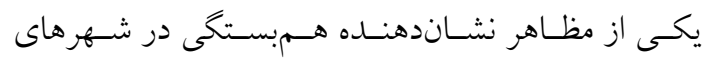

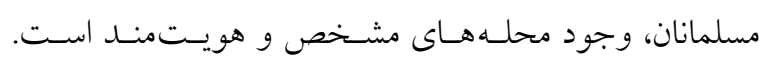

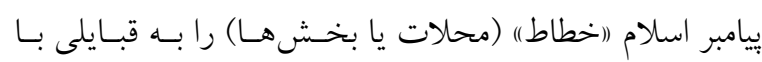
ييشينهاى قومى متفاوت، باوجود همخن بودن، بــون توجـهـ
در جدول شماره 1، نظرات بزوهشخران مختلف از يازده

منبع مختلف در باب ابعاد اجتماع محلى يايدار آمده است.

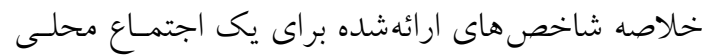
بايدار در يزّوهش هاى مختلف يس از تحليل و خلاصهسـازى و حذف كدهاى تكرارى، در قالب بيست و سه شاخص و بـا تفكيك در سه بعد؛ (اعملكردى - كالبدى)، (اهويتى - ادراكى) و ((اجتماعى))در تصوير زير ارائه شده است (تصوير Y).

\section{r-r. اصول اجتماعى اسلام و شهرسازى مسلمانان}

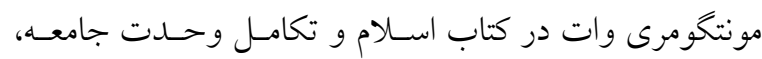
بيان مى كند: نامى كه انسانها يا مكاتب حاكم بر زنسـدى شـان

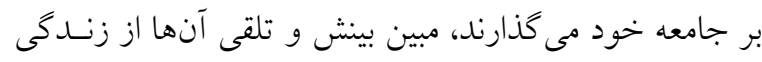
اجتمـاعى اسـت و بــراى فهـم تلقـى اسـلام از جامعـه، بايسـا

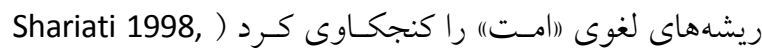
36). شريعتى مفهوم امت را بسيار مترقى تر و يويـاتر از سـاير مفاهيم، در اين حوزه مىبيند. وى تصريح مسى كنـد كـه سـاير اصطلاحات مشابه، ايستا هستند و تنها (امت)) است كه بويا به نظر مىرسد. - ا.

ايزوتسو معتقد است (امت)) با هر جيز مرتبط بـا فرهنــ

اسلامى، ارتباط دارد. قرآن بر مبناى (امت)، انديشهاى تـازه را در خصوص وحدت اجتماعى عرضه كرد كـهـ ايسن وحسدت، 
بازنكرى اصول و شاخصهاى "اجتماع پايداره بهمنظور كاربست در شهر سازى جوامع اسلامى در عصر جهانىشن

Michell 2009, ) حمامهاى عمومى و بازار زندگى مى كردند

ج) روابط همسايكَى: در ديسن اسـلام، آنجنـان در مـورد

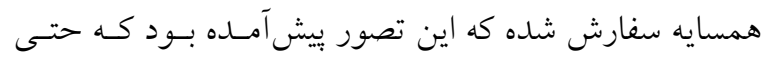

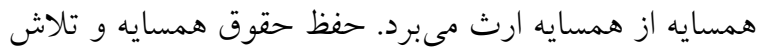
براى برقرارى روابط محكم همسـايكى، از مهـمتـرين مـوارد

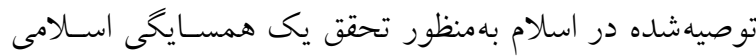
است (Mortada 2007, 52). مرتضى - شهرساز اسلامى - بيان مى كنــ كـه مسـلمانان

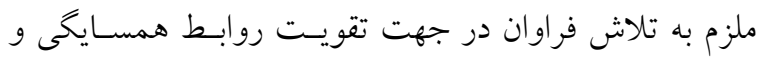

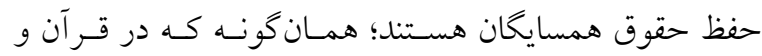

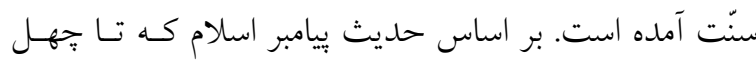

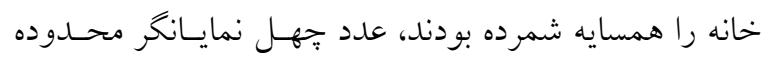

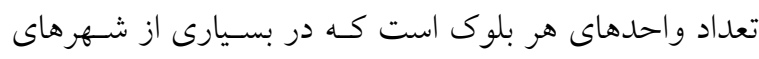

سنتى مسلمانان ديده مىشود (Mortada 2007, 117). د) عمل به شرايع دينى - اجتماعى: در نشاهِ قر آنى، تنهـا

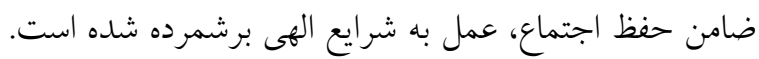

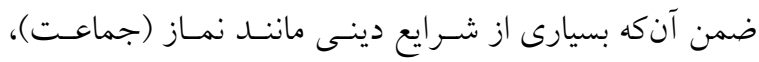

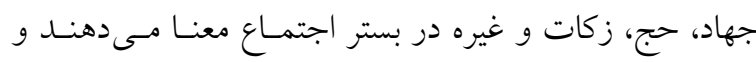
انجام آنها به حفظ و تقويت امت اسلامى منجر خواهد شد. وجود مسجد در مركز محلهها در شهرهاى مسـلمانان را

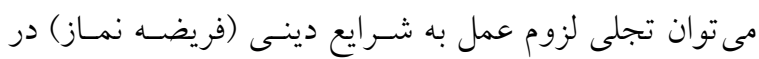

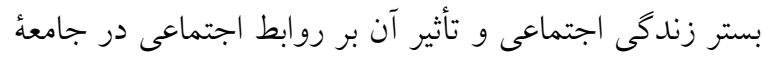

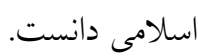

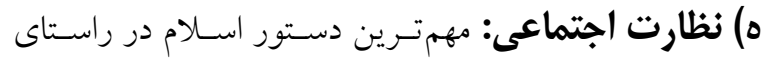

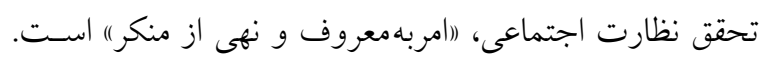
جامعه در اسلام، بر مبناى اين فريضه، قـوام مسى كيـــد و ايسن

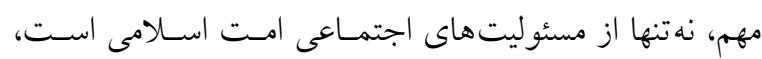

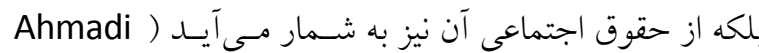

.(2009, 6

در شهرهاى مسلمين، بن بستهـا، بازارجـهـهـا، ميــان و

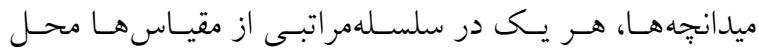

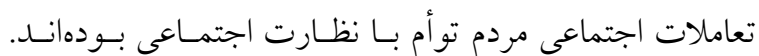
عبدالستار عثمان، بيان مى كند معابر و كذر كاههاى اختصاصى
به دارايى يا تنخدستى ايشان مىبخشيدند (Hakim 2002, 76). فرم شهرى محيط مصنوع مسلمانان، بلطور عمـانه بـراى

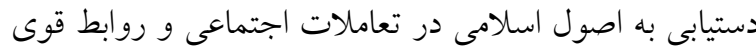

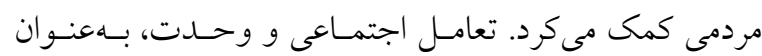
اصول كليدى جارجوب اجتماعى اسلام، منجر به ايجاد تراكم

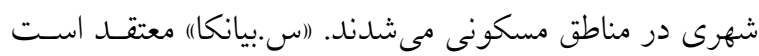

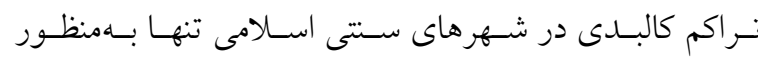
فشردهازى فضايى نيست، بلكه ارتباط اجتماعى به هم يبيوسته نيز در اين اصل، سهيم هستند (Mortada 2007, 117). عثمان نيز معتقد است اثر اين فشردگى خيلى آشكار بر زندگى شهر الشهر نيز منعكس شد؛ زيرا موجب همبستخى اجتماعى ميـان افراد

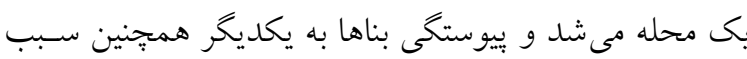

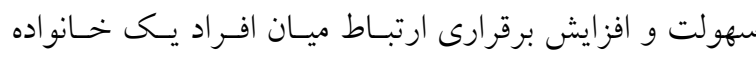
مىشد (Osman 1998, 46). هم جنين وجود بازار در شهرهاى سنتى مسلمانان نيـز بـا بـا

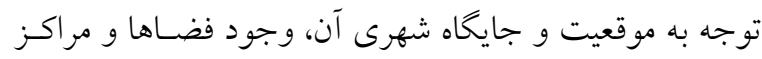

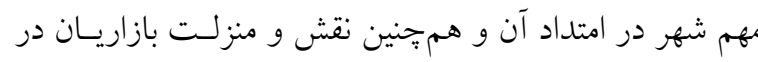

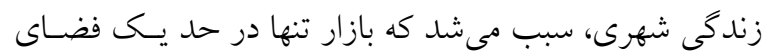

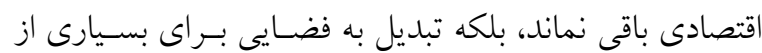
Pعاليتهاى اجتماعى شود ( Pourjafar \& Mahmoudinejad,

.2009

ب) عدالت اجتماعى: عدالت اجتماعى، ويزگى كليـدى و

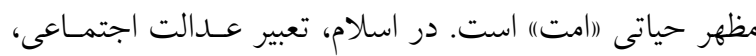

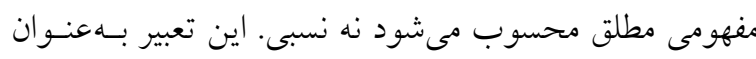

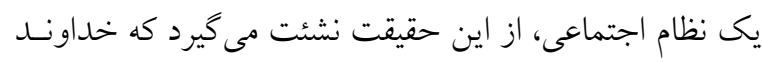

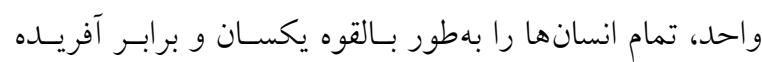

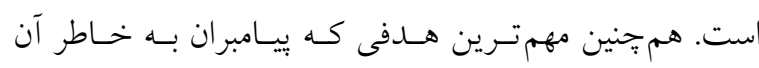

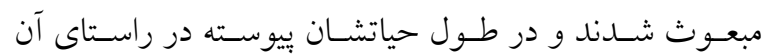
تلاش كردند، دستيابى به عـدالت بـوده اسـت ( Mortada . (2007, 49

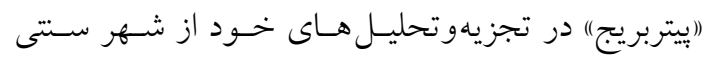

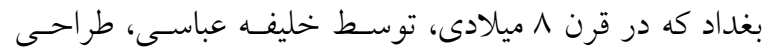

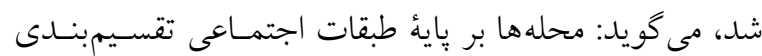
نشدهاند، هر يك بمامنزلة يكى بدنه منسجم بودهاند كـه فقيـر و

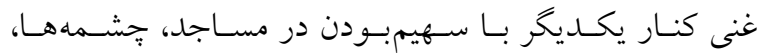


بود كه موجب آزار رسانيدن به ديخـران نمسىشـــــــازار نيـز مىبايستى مزاحمتى براى محله هاى مسكونى ايجاد نمسىكرد

.(Okhovvat et al. 2010, 46)

ز) ايمنى و امنيت: در قرآن مجيد از امنيت بهعنوان يكى از مهمترين صفات يك شهر، يادشـده اسـت. حضـرت ابـراهيم يس از تجديد بناى كعبه و بنيان نهادن شـهر مكـه، بـهــــوان مهمترين ويزگگى، از خدا مىخواهد كه اين شهر را (امن) قرار بلدهل، اصلى كه بهعنوان بيششرط برقرارى روابـط اجتمـاعى در يك شهر محسوب مى شود. خلاصه مباحث ارائسهـــه در ايسن قسـمت، در جـدول

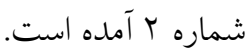

\section{" إ. يافته ها، تحليل و بحث}

همان گونه كه اشاره شد، تحليل دادهها در اين مقاله، بـه شـيؤ (استدلال منطقى) انجام مىشود. به كمك اين روش، ابتــدا دو

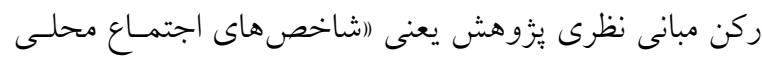

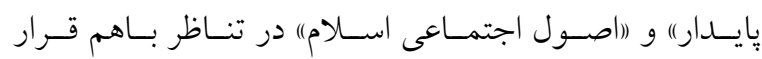

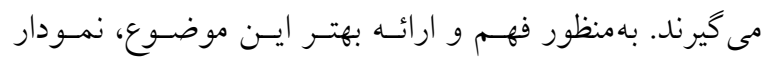

كه درهاى آن به روى غريبه هــا بسـته مسىشــ يكسى از علـل سهولت برقرارى ارتباط ميان سـاكنان يـك كو جــهـ بـه شـمار مىرفت (Osman 1998, 85). و) رعايت حقوق ديكران: قاعده مهمى در فقه اسلامى بـهـ نام (لاضرر)" وجود دارد كه به معنى نفى مشـروعيت هركونسه ضرر و اضرار در اسلام است. بر اين اسـاس، هـيج فـردى در

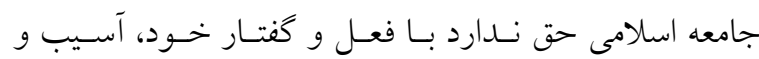
ضررى را متوجه ساير افراد جامعه كرداند. به عقيده ((محمد عبدالستّار عثمان)، اولـين و فراخيرتـرين قاعده مؤثر بر ساخت شـهرهاى مســلمانان، قاعـــهُ (لا ضـرر) است كه از ييامبر اسلام نقل شده است. بر اساس ايسن حكـم،

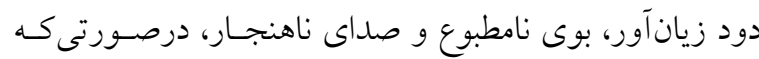
بيشازحد مجاز بودند، سه نشانه بـهـ شـمار مسىرفتنـد كـه از

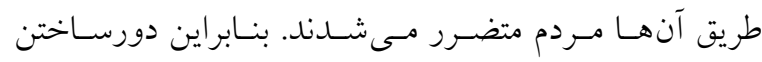
تأسيسات و صنايع از مناطق مسكونى واجب شـد ( Osman

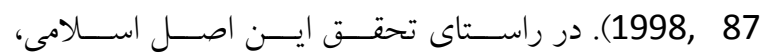

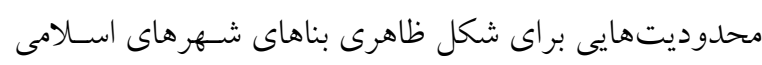

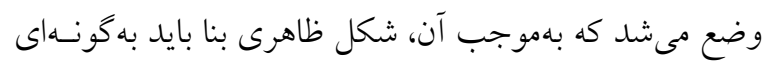

جدول r: اصول اجتماعى اسلام و تجلى آن در شهرسازى مسلمانان

Table 2: Social principles of Islam and its manifestation in Muslim urbanization

\begin{tabular}{|c|c|c|}
\hline تجليات فرمى در شهرسازى مسلمانان & اصول اجتماعى اسلام & \\
\hline 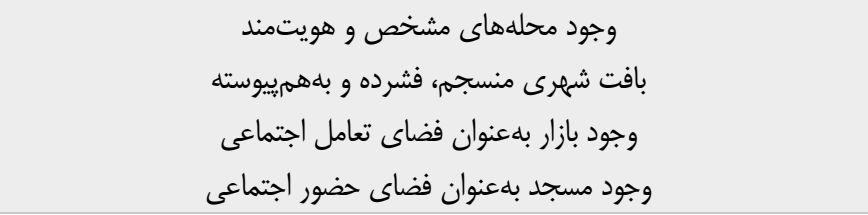 & روابط مستحكم و تعاملات اجتماعى & 1 \\
\hline 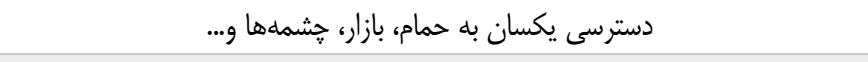 & 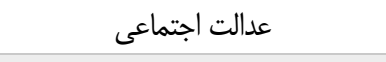 & r \\
\hline عدد جِل واحد بلعنوان اندازه بلوكهاى همسايكى؛ تجلى توجه به روابط همسايكى & روابط همسايخى & r \\
\hline 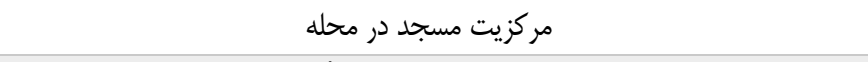 & 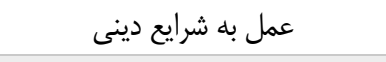 & f \\
\hline 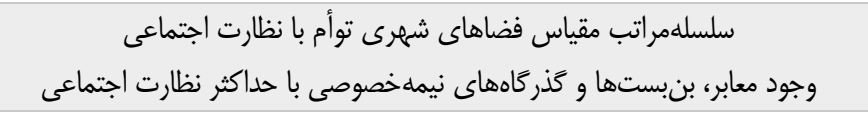 & 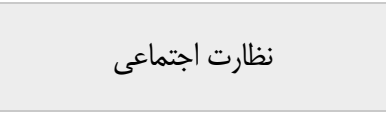 & $\Delta$ \\
\hline 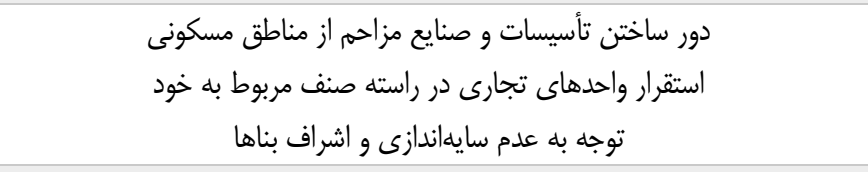 & رعايت حقوق ديكران & q \\
\hline امكان نظارت اجتماعى و توجه به محرميت در منسجم و نفوذنايذير & 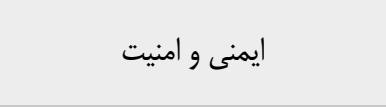 & $\checkmark$ \\
\hline
\end{tabular}


بازنكرى اصول و شاخصهاى 》اجتماع پايداره" بهمنظور كاربست در شهر سازى جوامع اسلامى در عصر جهانىشدن

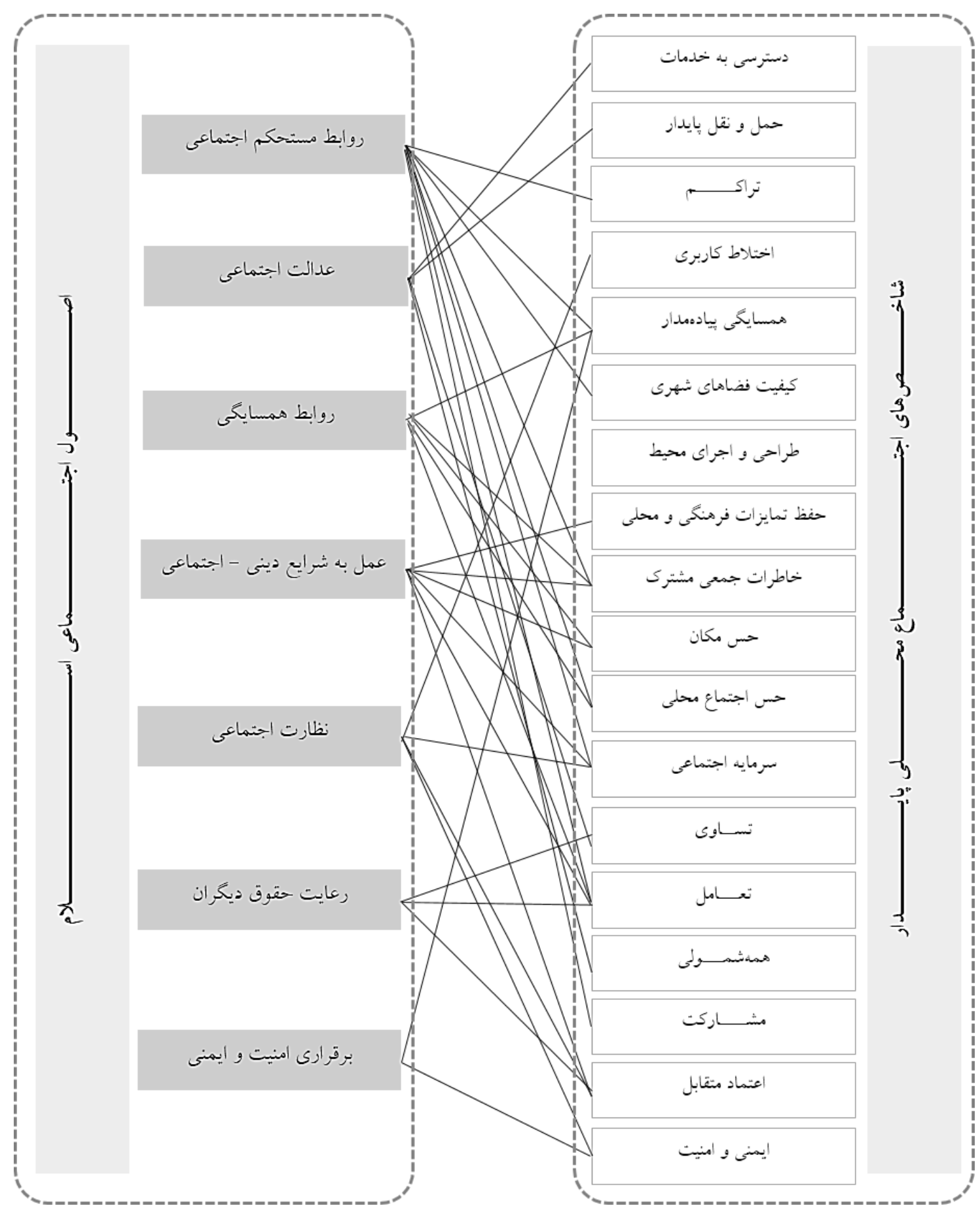

تصوير "ّ: تناظر اصول اجتماعى اسلام و شاخصهاى اجتماع محلى بايدار

Fig. 3: Correspondence between social principles of Islam and the indices of sustainable community

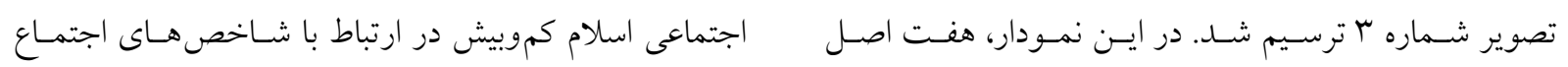

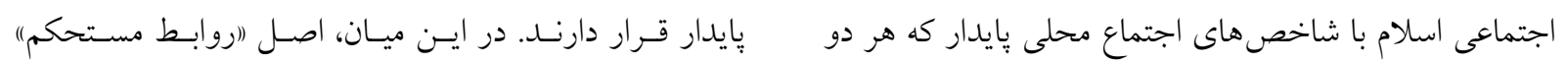

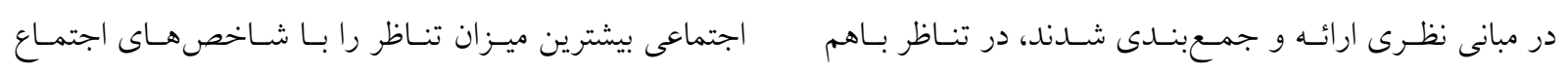

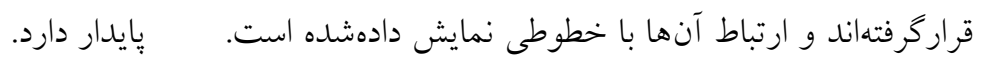

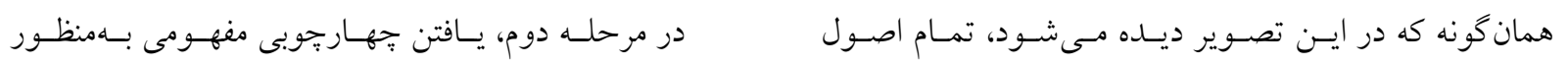


مصاديق جهانى شدن است كه در برخى مـوارد مسى توانـــ بـهـ

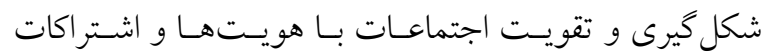
فرهنكى - مذهبى منجر شود. تحقق (امت واحسـده) بـهـعنـوان كليد مفهوم اجتماعى اسلام، در ذيل همين نخاه، مسىتوانــ در سر راستاى رويكرد جهانىشدن قرار داشته باشد.

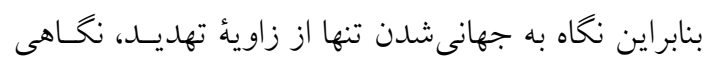
سطحى و غيرواقعى است. مى توان به جـالشهــاى يادشــده از زاوية فرصت نخريست و راهبردهاى فرصت سازانه بـراى آن، ارائه كرد. جدول شـمارة سا، بـر مبنـاى نمـودار شـمارة ع تنظيم و تدوين شده است. در اين جدول، براى مواجهه با هـر يـك از جالش هاى اجتماعى شش كانهُ جهانى شدن، بر اسـاس اصـول

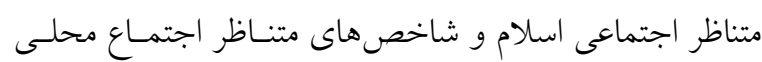

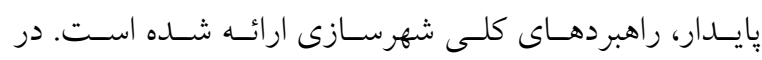
يُزوهش هاى آتى مى توان به كمك روشهاى كمّى و ميــانى،

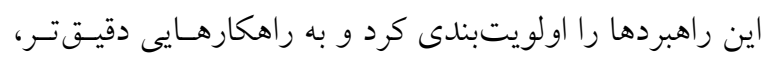
عملى تر و كاربردى تر ارتقاء داد.
استفاده از اصول اجتماعى اسلام از يكسو و حسوزهُ مفهـومى يايدارى اجتماعى از سوى ديخر، در مواجهـه بـا جــالشهـاى اجتماعى جهانى شدن در شهرها مــنظر بـوده اسـت. بـه ايسن

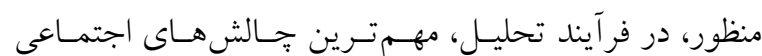
جهانىشدن، در تناظر با ويزّى هاى اجتمـاع محلسى بِيـدار و اصول اجتماعى اسلام قرار داده شدند. اين خالشها در تقابـل

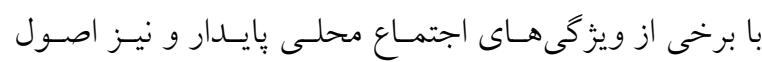

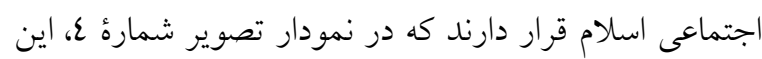
تقابل مشاهده مىشود. لازم به يادآورى است كـه بسـيارى از ״الشهاى اجتماعى جهانى شدن جنبههاى متناقضى دارند كـه

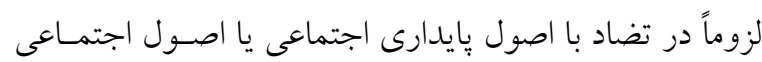

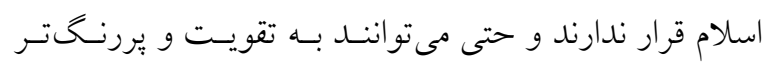
شدن اين اصول كمك كنند. بهعنوانمثال، جهانى شدن اخرجـهـ از يكسو منجر به تضعيف ارزشهاى بومى و محلى مىشـود

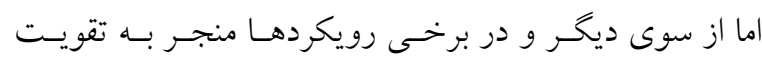

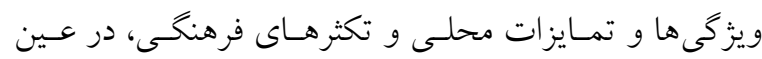
تفكر جهانى مىشود. از بين رفتن مرزهاى سياسى نيز از ديخر

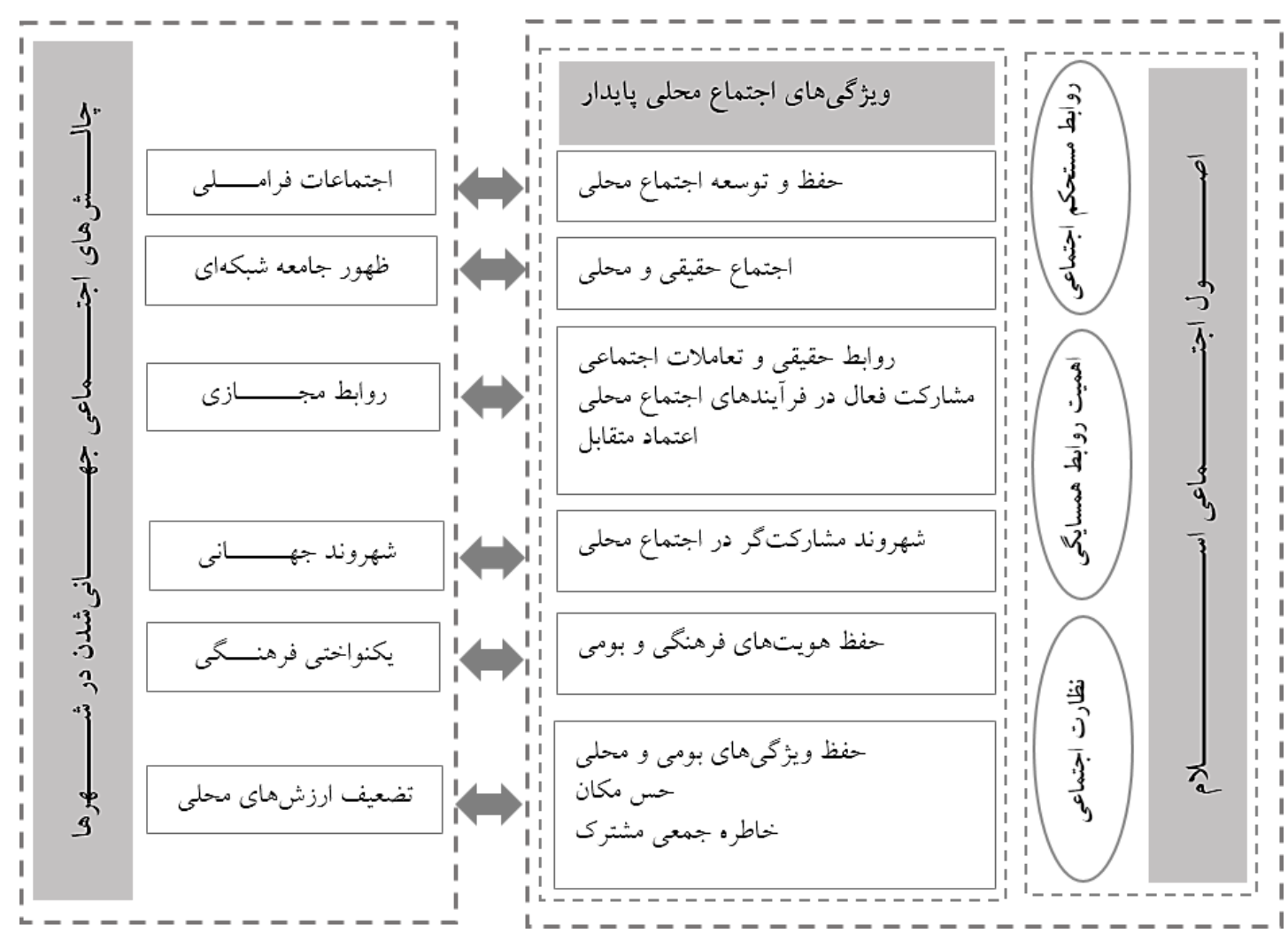

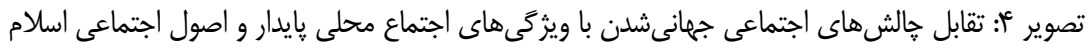

Fig. 4: Social Challenges of Globalization, Sustainable Community Characteristics and Social Principles of Islam 
بازنكرى اصول و شاخصهاى "اجتماع بايدار" بهمنظور كاربست در شهر سازى جوامع اسلامى در عصر جهانى شدن

جدول ": توصيهها و راهبردها بر مبناى اصول اجتماعى اسلام و شاخصهاى اجتماع محلى بايدار

Table 3: Recommendations and strategies based on Islamic social principles and sustainable community indicators

\begin{tabular}{|c|c|c|c|c|}
\hline \multicolumn{3}{|c|}{ 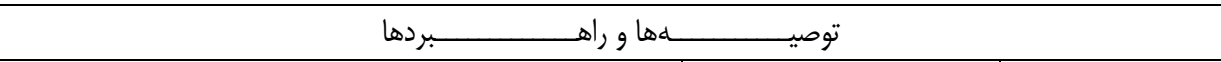 } & \multirow{2}{*}{ جهانى شالشهاى اجتماعى } & \\
\hline (راهكارهاى شهرسازى & اجتماع محلى پايدار & اصل در اجتماعى اسلام & & \\
\hline ارتقاء كيفيت فضاهاى شهرى در مقياس محلى و همسايكى & \multirow{3}{*}{ كمسيت اجتماع يادمادلى مضار } & \multirow{3}{*}{ نظارت اجتماعى مستحكم } & \multirow[t]{3}{*}{ ظهور جامعه شبكاى } & 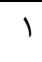 \\
\hline طراحى فضاهاى بيادهمدار & & & & \\
\hline اختلاط كاربرى بهمنظور ارتقاء سرزندىى و حضوريذيرى فضا & & & & \\
\hline ارتقاء كيفيت فضاهاى شهرى در مقياس محلى و همسايكى & \multirow{4}{*}{ 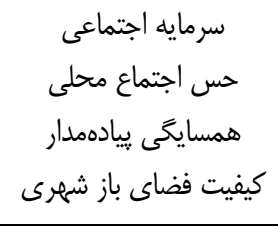 } & \multirow{4}{*}{ 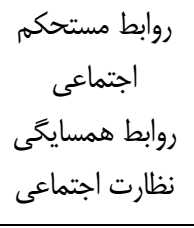 } & \multirow{4}{*}{ 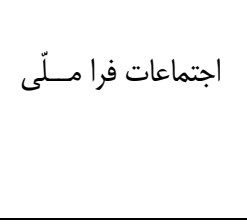 } & $r$ \\
\hline اختلاط كاربرى بلهنظور ارتقاء سرزندگى و حضوريذيرى فضا & & & & \\
\hline تقويت قرار كاههاى رفتارى براى گرووههاى مختلف استفاده كنده & & & & \\
\hline طراحى فضاهاى يبادمدار & & & & \\
\hline ارتقاء كيفيت فضاهاى شهرى در مقياس محلى و همسايخى & \multirow{3}{*}{ 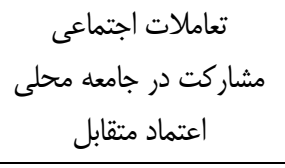 } & \multirow{3}{*}{ نظارت اجتماعى همايكى } & \multirow[t]{3}{*}{ 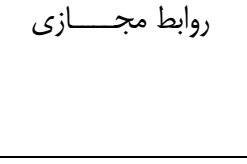 } & $r$ \\
\hline تقويت قرار كاههاى رفتارى براى گروههاى مختلف استفادهكنده & & & & \\
\hline طراحى فضاهاى يبادهمدار & & & & \\
\hline تقويت و تسهيل فرآيندهاى مشار كتى در طراحى، برنامهريزى و & \multirow{4}{*}{ مشاركت در جامعه محلى } & \multirow{4}{*}{ نظارت اجتماعى همايكى } & \multirow[t]{4}{*}{ شهروند جهــــــــــى } & $r^{c}$ \\
\hline مديريت فضاهاى محلهاى & & & & \\
\hline تقويت قرار كاههاى رفتارى براى گرووههاى مختلف استفاده كنده & & & & \\
\hline فرصتسازى فضاهاى محلهاى براى احساس تعلق از سوى & & & & \\
\hline توجه به تمايزات بومى - محلى در طراحى فضا & \multirow{4}{*}{ حفظ تمايزات فرهنكى - } & \multirow{4}{*}{ دينى - اجتماعى به شرايع } & \multirow[t]{4}{*}{ 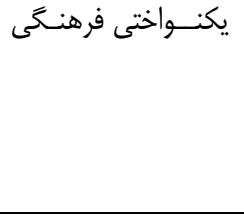 } & $\Delta$ \\
\hline طراحى فضاهاى كوجكمقياس & & & & \\
\hline استقرار كاربرى هاى فرهنكى - مذهبى متناسب با روحيه فضا & & & & \\
\hline استفاده از نمادها و نشانههاى فرهنكى در طراحى فضا & & & & \\
\hline توجه به تمايزات بومى - محلى در طراحى فضا & \multirow{4}{*}{ 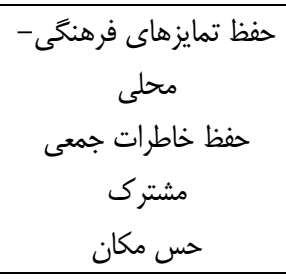 } & \multirow{4}{*}{ 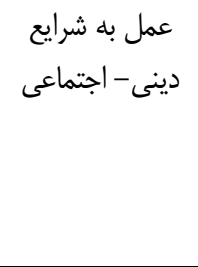 } & \multirow{4}{*}{ تضعيف ارزشهاى - محلى } & \\
\hline طراحى فضاهاى كوجكمقياس & & & & \\
\hline حفظ و تقويت عناصر محيطى خاطرهانكيز & & & & \\
\hline استقرار كاربرى هاى فرهنگى - مذهبى متناسب با روحيه فضا & & & & \\
\hline
\end{tabular}

\section{نتيجه كيرى}

جهانى شدن در شهرها كدام است؟ جّكونه مىتوان از اصول اجتماعى اسلام و بروز آن در سنت شهرسازى مسـلمانان از يكسو و شاخص هاى اجتماع محلى پيايدار بهمنظور مواجهه با جالش هاى اجتماعى جهانى شدن در شهرها بهره كرفتـ؟ ضمن اين دو سؤال اصلى، يرسش فرعى ديخرى نيز مــنظر

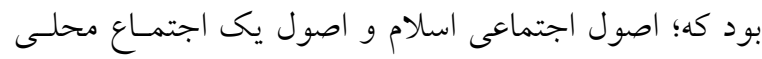
پايدار در جهارجّوب مفهومى توسعه پِيدار تا جهه ميـزان در
جهانى شدن با همـهُ بيامــهاى مثبـت و منفـى خــود، بـراى جوامع شهرى، يديـدهاى ظهوريافتـه يـا در حسال ظهـور در بسيارى از شهرهاى بـزرى و كوجـى دنيـا اسـت. در ايـن نوشتار در يى تبيين نحوة كاربست اصول اجتماعى اسـلام و

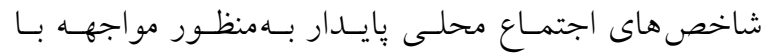
״الش هاى اجتماعى جهانى شدن در شهرها بوديم. سؤالهاى اصلى بزوهش اين بودند كه مهمترين جالش هاى اجتمـاعى 
كرفتند. ضمن طى اين فر آيند بهمنظور پِاسخ به يرسش فرعى

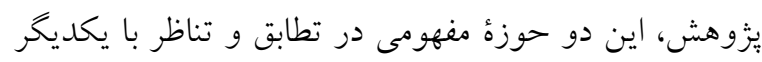
قرار گرفتند. در نمودار س، حاصل اين تناظر و ميزان ارتباط و اشتراى اصول اجتماعى اسلام با شاخص هاى اجتماع محلى يايدار ديده مىشود. طبق اين تحليل، توصيه اسلام به (اروابط مستحكم اجتمــاعى" بيشـترين ميـزان فصـل مشـترك را بـا شاخص هاى اجتمــاع محلـى بايسـار دارا اسـت. در نمـودار تصوير شماره ع و جدول شـماره ا، يرسـش دوم يـزوهش

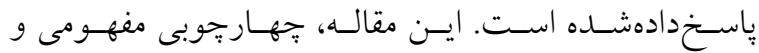
راهبردى بهمنظور مواجهه با جالشهاى اجتماعى جهانىشدن

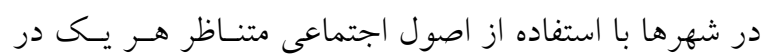
اسلام و نيـز شـاخصهــاى متنـاظر اجتمـاع محلـى پيايسـار، بهمنظور كاربست در طراحى و برنامهريزى شهرى ارائه داده

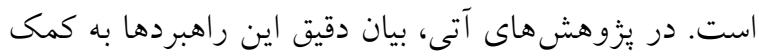

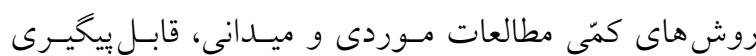
خواهد بود.
تشابه و اشتراى باهم قرار دارند؟ بـهـنظـور ياسـخ بـه ايسن يرسش ها ضمن مرور ادبيات در سه حوزهُ اصلى مبانى نظرى

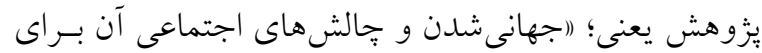

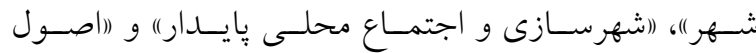
اجتماعى اسلام و شهرسازى مسلمانان)، و با استفاده از روش

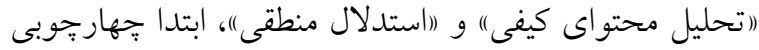
براى جالشهاى اجتماعى جهانى شدن تدوين شد؛ بنا بر اين

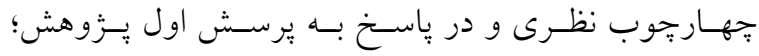
مهمترين جالش هاى اجتماعى جهانى شـدن بـراى شـهرها را مى توان در شش مفهوم (ظهور جامعه شبكهاى)، (اجتماعات فرا ملى")، ("روابط مجازى)، (اشهـروند جهـانى)، ("يكنـواختى فرهنگى") و (تضعيف ارزشهاى بومى - محلى)، خلاصه كرد. بهمنظور ياسخ كويى به برسش دوم، نظـرات انديشـمندان در باب اصول و شـاخص هـاى يـى اجتمـاع محلى يايـدار از يكسو و نيز اصول اجتماعى اسـلام و تجلسى آن در سـنت تاريخى شهرسازى مسلمانان از سوى ديخر، موردمطالعه قرار

\section{يحىنوشتها}

I. اصطلاحى كه توسط زيل دلوز - فيلسوف فرانسوى- از زيستشناسى وارد فلسفه شده است.

\section{Sustainable Community}

3. Cosmopolitan

4. Culture of Virtual Reality

\section{فهرست منابع}

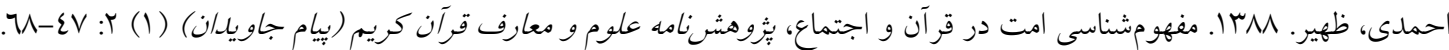

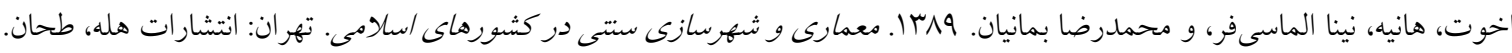

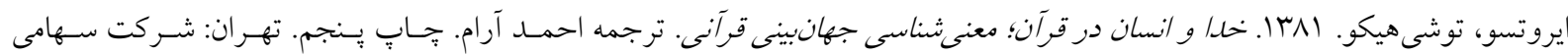

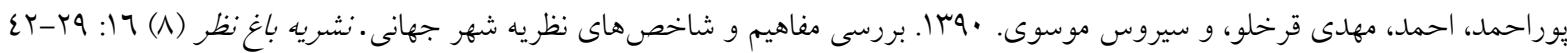

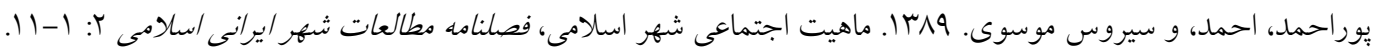
يورجعفر، محمدرضا، و هادى محمودىنزاد. 1M 1 ا. طراحى شهرى و سرمايه اجتماعى در فضاهاى شهرى. تهران: انتشارات هله.

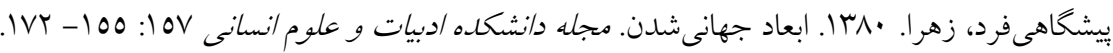

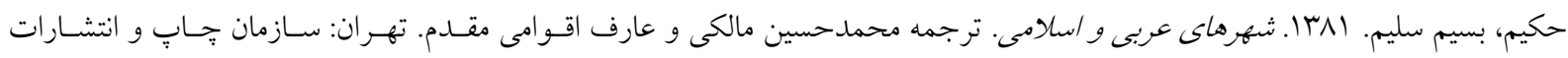
وزارت فرهنخ و ارشاد اسلامى.

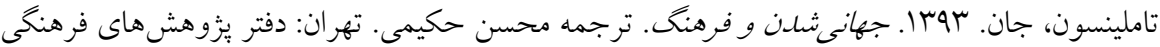

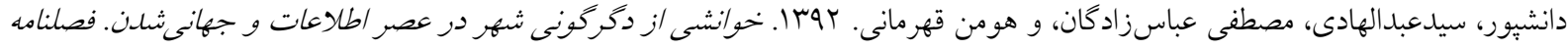


بازنخرى اصول و شاخصهاى 》اجتماع پايدار" بهمنظور كاربست در شهرسازى جوامع اسلامى در عصر جهانىشدن

$$
\begin{aligned}
& \text { (1) }
\end{aligned}
$$

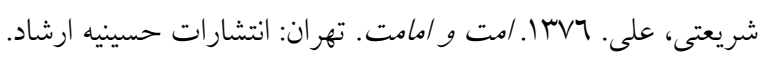

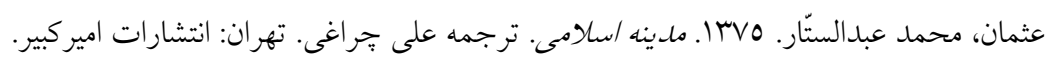

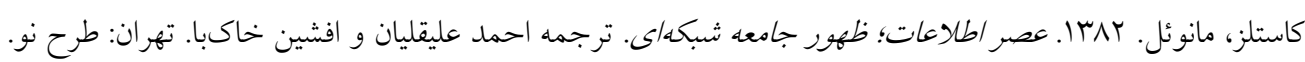

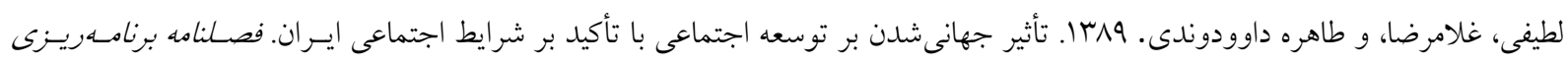

$$
\begin{aligned}
& \text { رفاه و توسعه اجتماعى (1) r: } \\
& \text { مرتضى، هشام. VIYI اصول سنتى ساختوساز در /سلام. ترجمه ابو الفضل مشكينى و كيومرث حبيبى. تهـران: انتشـارات مركـز مطالعـات و } \\
& \text { تحقيقات معمارى و شهرسازى. }
\end{aligned}
$$

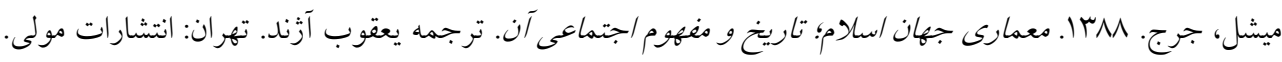

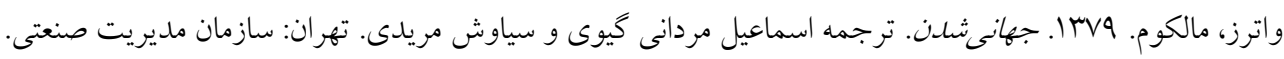

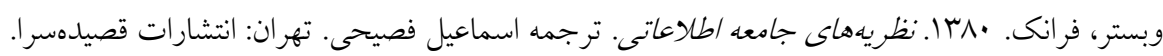

Ahmadi, Z. 2009. The Concept of Ummah in Quran and Society. Journal of Science and Education of the Holy Quran 1 (2)47-68. [In Persian]

Arundel, R, \& R. Ronald. 2015. The Role of Urban Form in Sustainability of Community: The Case of Amsterdam. Environment and Planning B: Planning and Design (1)44: 33-53.

Barron L., \& Gauntlett E. 2002. Model of Social Sustainability. Western Australia Council of Social Services. (WACOSS).

Bramley, G., Brown, C., Power, S., \& Dempsey, N. 2006. What is Social Sustainability and how do Existing Urban Forms Perform in Nurturing it? London: UCL University.

Bramley, G., \& S. Power. 2009. Urban form and social sustainability: the role of density and housing type. Environment and Planning B: Planning and Design 36: 30-48.

Bramley, G., Dempsey, N., Power, S., Brown, C. and Watkins, D., 2009. Social sustainability and urban form: evidence from five British cities. Environment and planning A, 41(9): 2125-2142.

Castells, M. 2002. The Information Age: The Rise of the Network Society, Translated by Ahmad Aligholian and Afshin Khakbaz, Tehran: Tarh e No Press. [In Persian]

Chan, E., \& G. KL Lee. 2008. Critical Factors for Improving Social Sustainability of Urban Renewal Projects. Social Indicators Research (85)2: 243-256.

Colantonio, Andrea. 2009. Social sustainability: linking research to policy and practice. In: Sustainable development: a challenge for European research. Belgium: Brussels.

Daneshpour S. A. M. Abbaszadegan, \& H. Ghahremani. 2014. A Review of Urban Transformations during InformationGlobalization Era. Armanshahr Architecture and Urban Development Journal 6(11): 223-238. [In Persian]

Hakim, Basim Salim. 2002. Arabic Islamic Cities. Translated by Aref Aghvami Moghaddam \& Mohammad Hosein Malek Ahmadi. Tehran: Printing and Publishing Organization of Ministry of Culture and Islamic Guidance. [In Persian]

Hemani, Sh., \& A. Kumar Das. 2015. Humanising urban development in India: call for a more comprehensive approach to social sustainability in the urban policy and design context. International Journal of Urban Sustainable Development (2)8:1-30.

Hemani, Sh., \& A. Kumar Das and Anirban Chowdhury. 2017. Influence of urban forms on social sustainability: A cas of Guwahati, Assam 22: 168-194.

Hsiu- Fang, Hsieh, \& S. E. Shanon. 2005. Three Approaches to Content Analysis. Qualitativr Health

Research 15(9): 1277-1288.

Izutsu, T. 2001. God and Human in Quran. Translated by Ahmad Aram, Fifth Edition. Tehran: Publication Joint Stock Company. [In Persian]

Latifi, Gh. \& T. Davoodvandi. 2009. The Impact of Globalization on Social Development By Emphasis on Iran's Social Condition. Social Development and Welfare Planning 1(3): 179-202. [In Persian]

Mazumdar, S., V. Learnihan, Th.s Cochrane, \& R. Davey. 2017. The Built Environment and Social Capital: A Systematic Review. Environment and Behavior (50)2: 119-158.

Michell, G. 2009. Architecture of The Islamic World. Translated by Yaqub Azhand. Tehran: Mola Press. [In Persian]

Mortad, H. 2007. Traditional Islamic Principles of Built Environment. Translated by Abolfazl e Meshkini and Qeumars Habibi. Tehran: Architecture and Urban Studies and Research Center. [In Persian] 
ODPM .2006. EU Ministerial Informal on Sustainable Communities. London: European Evidence Review Papers.

Okhovvat, Hanie, Nina Almasifar and Mohammadreza Bemanain. 2010. Traditional Architecture and Urban Design in Islamic Countries, Tehran: Tahan Press. [In Persian]

Oktay, D. 2009. Urban design for sustainability: A study on the Turkish city. The International Journal of Sustainable Development and World Ecology 11: 24-35.

Osman, M. A. S. 1998. Islamic City. Translated by Ali Cheraghi, Tehran: Amirkabir Press. [In Persian]

Partridge, E. 2005. Social sustainability': A useful theoretical framework? In: Australasian Political Science Association Annual Conference. Dunedin. New Zealand.

Pishgahifar, Z. 2001. The Dimensions of Globalization. Journal of the Faculty of Literature and Humanities (157): 155-172. [In Persian]

Pourahmad, A., M, Gharakhloo, \& S. Mousavi. 2011. A Study of Concepts and Indicators of the Global City Theory, Bagh-E Nazar 8 (16): 29-42. [In Persian]

Pourahmad, A. \& S. Mousavi. 2010. The social nature of Islamic city. Iranian- Islamic City 1(2):1-11. [In Persian]

Pourjafar, M., \& H. Mahmoudinejad. 2009. Urban Design and Social Capital in Urban Spaces. Tehran: Hele Press. [In Persian]

Shariati, A. 1998. Ummah and Imamah. Tehran: Hoseinie Ershad Press. [In Persian]

Tabatabaee, S. M. H. 1996. Tafsir Al-Mizan, Vol. 4. Qom: Islamic Publications Office. [In Persian]

Tomlinson, J. 2014. Globalization and Culture. Translated by Mohsen Hakimi. Tehran: Iran Cultural Studies. [In Persian]

Waters, M. 2000. Globalization. Translated by Esmaeil Mardani Givi and Siavash Moridi. Tehran: Industrial Management Institute. [In Persian]

Webster, F. 2001. Theories of the Information Society. Translated by Esmaeil Ghadimi, Tehran: Ghasidesara Press. [In Persian]

Yung, E., H. Kwan, E. Hon Wan Chan, \& Y. Xu. 2011. Sustainable Development and the Rehabilitation of a Historic Urban District-Social Sustainability in the Case of Tianzifang in Shanghai. Sustainable Development (2)22: 95- 112. 